\author{
PAWEE ZAJACC \\ Uniwersytet im. Adama Mickiewicza \\ w Poznaniu, Wydział Teologiczny
}

\title{
GIOVANNI ANDREA ARCHETTI I STANISEAW AUGUST PONIATOWSKI. OBRAZ KRÓLA I WZAJEMNYCH RELACJI W DEPESZACH NUNCJUSZA DO SEKRETARIATU STANU STOLICY APOSTOLSKIEJ Z LAT 1776-1784
}

\begin{abstract}
Abstrakt: W artykule omówione zostały wzajemne stosunki króla Stanisława Augusta Poniatowskiego oraz Giovanniego Andrei Archettiego, nuncjusza papieskiego w Rzeczypospolitej w latach 1776-1784. Informacje na temat polskiego króla były ważną częścią depesz przesyłanych przez nuncjusza do rzymskiego sekretariatu stanu. Królowi zależało na pozytywnym wizerunku władcy. Kilka potencjalnie kryzysowych sytuacji na płaszczyźnie państwo-Kościół rozwiązano w tym okresie ugodowo.
\end{abstract}

Słowa kluczowe: Stanisław August Poniatowski, Giovanni Andrea Archetti, Pius VI, dyplomacja papieska, nuncjatura, sejm 1776, cystersi, Ląd, Bledzew, opactwa komendatoryjne, Kajetan Sołtyk, Kodeks Zamoyskiego, Otton Stackelberg, Wiśniowiec.
A bstract: The articlestudies mutual relations between King Stanisław August Poniatowski and Giovanni Andrea Archetti, the papal nuncio in the Commonwealth from 1776 to 1784. Information about the Polish king was an important part of the dispatches sent by the nuncio to the Roman secretariat of state. The king was concerned with creating a positive image of a ruler respecting the rights of the Roman Catholic Church. During this period several potential crises involving the state and the Church were resolved amicably.

Keywords: papal diplomacy, papal nuncio, Secretariat of State at the Apostolic See, Stanisław August Poniatowski, Giovanni Andrea Archetti, Pius VI, Cistercian abbeys in Ląd and Bledzew, Otto Stackelberg, Kajetan Sołtyk, Andrzej Zamoyski.

Pochodzący z Brescii Giovanni Andrea Archetti (1731-1805) ${ }^{1}$ w 1774 r. został wymieniony przez Stanisława Augusta Poniatowskiego wśród

1 Zarys biografii oraz podstawowa bibliografia dot. Archettiego w: Acta Nuntiaturae Polonae, t. 54: Ioannes Andreas Archetti (1776-1784), vol. 1: (8 IV 1775-25 VII 1776), wyd. P. Zając OMI, Cracoviae 2013. Dalej cyt. jako ANP 54/1. Dziękuję Dorocie Dukwicz za lekturę pierwszej wersji artykułu oraz cenne uwagi. 
trzech kandydatów na następcę Giuseppe Garampiego, przeznaczonego już na nuncjusza w Wiedniu. Król Archettiego osobiście nie znał. Spodziewał się, że nowy nuncjusz będzie osobą szlachetnie urodzoną, towarzyską, zdolną do prowadzenia miłej konwersacji, jednocześnie kimś raczej przeciętnym, bez ambicji politycznych ${ }^{2}$. Gdy wczesną wiosną 1775 r., krótko po wyborze na Stolicę Apostolską, Pius VI przeznaczył Archettiego do Warszawy, polski minister pełnomocny w Rzymie, Tommaso Antici, bez dalszych konsultacji z królem i z protektorem Rzeczypospolitej, kard. Franceskiem Albanim, upewnił papieża, że wybór zostanie przez Stanisława Augusta zaakceptowany ${ }^{3}$. Dlatego, choć w Rzymie zwlekano z opublikowaniem oficjalnej listy nowych nuncjuszy, sekretariat stanu w nocie ministerialnej z 22 kwietnia 1775 r. poinformował króla o decyzji w sprawie Archettiego. W Warszawie zapanowała konsternacja. Stanisław August był niezadowolony z postępowania Anticiego i sposobu rozstrzygnięcia w kurii rzymskiej o nominacji. Choć rzeczywiście sam podał nazwiska trzech kandydatów, to jednak liczył na to, że Garampiego zastąpi Vincenzo Ranuzzi i że zostanie w tej sprawie dodatkowo zapytany o zdanie ${ }^{4}$. Wydaje się, że Antici prowadził jakąś misterną grę. W pierw-

${ }^{2}$ G. Platania, Instrukcje dworu polskiego w zwiazku z konklawe po śmierci papieża Klemensa XIV (1774), w: „Informationes. Biuletyn Papieskiego Instytutu Studiów Kościelnych" (Rzym-Warszawa), 1980, nr 2, s. 44-45, 50. Tego rodzaju oczekiwania wydają się echem negatywnego stosunku dworu królewskiego do Angela Marii Duriniego starania o jego odwołanie, nie bez nacisków Rosji, zaczęto podejmować już w 1768 r., zatem niespełna rok po rozpoczęciu misji w Rzeczypospolitej. Garampi zanotował: „Il marchese Antici mi ha letta una lettera di Ghigiotti dei 2 novembre in cui dice che Mgr Durini, dopo ricevute le nostre riprensioni, le mette in ridicolo, e che non vuol darla vinta ne a noi ne al re. La corte ne vive in sospetto risguardandolo come un segreto emmissario della Francia: pel quale motivo desiderebbe che N.S. lo allontanasse dal Regno". Archivio Segreto Vaticano (dalej: AV), Fondo Garampi 52, notatka Garampiego, 30 XI 1768. W polskiej historiografii, począwszy od pracy Macieja Loreta, Zamach na Stanisława Augusta w świetle źródeł watykańskich („Biblioteka Warszawska”, R. 71, 1911, t. 1 (281), s. 548), nie ustają dyskusje nad oceną działalności nuncjusza, por. W. Kęder, Stolica Apostolska wobec Rzeczypospolitej w okresie Konfederacji Barskiej, 1767-1773, Opole 2006; M. Wrana, Angelo Maria Durini. Poeta i polityk w purpurze. Zarys działalności literackiej, kulturalnej i politycznej nuncjusza w Polsce (1767-1772), Kraków 2013.

${ }^{3}$ Ogólne informacje o dyskusjach nad nominacją Archettiego podał P. Zając, Polska i Polacy w korespondencji nuncjusza Jana Andrzeja Archettiego, 1775-1784, w: Nuncjatura Apostolska w Rzeczypospolitej. Stan badań i perspektywy, red. T. Chynczewska-Hennel, K. Wiszowata-Walczak, Białystok 2012, s. 414-437.

${ }^{4}$ Vincenzo Ranuzzi (1726-1800) ur. w Bolonii w rodzinie senatorskiej, studiował w Rzymie i pełnił rozmaite funkcje w kurii papieskiej. Od 1775 r. był nuncjuszem w Wenecji, a od 1782 r. w Portugalii. Kreowany kardynałem na konsystorzu 14 lutego 1785 r., biretem udekorował go król Piotr III. Od 1785 r. był arcybiskupem Ankony. Zob. http://www2.fiu.edu/ mirandas/bios1785.htm\#Ranuzzi [dostęp: 17 III 2015]. Powody, 
szych dniach kwietnia 1775 r. zapewniał Archettiego, iż byłby nuncjuszem mile widzianym przez polskiego króla, ale ponieważ jego obecna pozycja w kurii wróży mu lepszą przyszłość, jako minister pełnomocny nie będzie wspierał jego kandydatury i skieruje uwagę papieża ku Ranuzziemu ${ }^{5}$. Jeśli rzeczywiście to uczynił, nominacja Archettiego na stanowisko nuncjusza w Rzeczypospolitej wynikałaby z osobistej decyzji Piusa VI, pragnącego, być może, zamanifestować, iż nominacje ważnych urzędników kościelnych zależą od jego suwerennej woli, nie zaś od sugestii władców. Skądinąd nie ma pewności, że Antici był wobec Archettiego szczery - wszak wbrew temu, co mu zapowiadał, poparł wobec papieża jego kandydature na stanowisko nuncjusza - trudno jednak zweryfikować powody, dla których miałby podejmować w tej kwestii aż tak wyrafinowane zabiegi.

Podczas krótkotrwałej burzy na polskim dworze związanej z rzymską decyzją pojawiły się wątpliwości dotyczące szlacheckich korzeni oraz majątku Archettiego. Ostatecznie dzięki delikatnej mediacji Garampiego pierwszy kryzys wokół nowego nuncjusza zażegnano ${ }^{6}$.

Pierwszy list do Stanisława Augusta Archetti napisał 22 lipca 1775 r., tuż po uzyskaniu oficjalnej nominacji z sekretariatu stanu ${ }^{7}$. Bratu Carlowi zwierzył się, że konieczność manifestowania czołobitności wobec osoby dotąd nieznanej budziła w nim mieszane uczucia. Nie był też zadowolony z powierzonej mu przez Piusa VI misji w dalekim, północnym kraju ${ }^{8}$. Prawdopodobnie nie był świadom, że zaledwie kilka miesięcy wcześniej królewskie veto wobec papieskiej nominacji mogło przysporzyć mu niemałych upokorzeń i nadwątlić karierę kurialną.

Taki był początek relacji między Stanisławem Augustem Poniatowskim i Giovannim Andreą Archettim, które w ciągu kolejnych 8 lat nie

dla których król przedkładał jego kandydaturę nad Archettiego, nie są znane. Sprawę opisał G. Garampi w liście do L.O. Pallaviciniego, Warszawa, 17 V 1775, AV, Segreteria dello Stato (dalej: Segr. Stato), Polonia 316, k. 133r-135v.

${ }^{5}$ G. A. Archetti do C. Archettiego, 8 IV 1775, Bergamo, Biblioteca Civica Angelo Mai (dalej: Bib. Civica A. Mai), Archivio (dalej: Arch.) Gamba, Scatola 3, fasc. 170.

6 „Fece dunque Ghigiotti la relazione al Re, il quale impressionato per la persona di Mgr Ranuzzi non aveva presenti le premure più anticamente fatte per Archetti. Nel che mi assicura Ghigiotti di avere usata ogni arte per condurre il Re a non attraversare punto la destinazione già fatta: espose le favorevoli nozioni che fin da due anni sono, da me, da vari suoi corrispondenti aveva avute su di Mgr Archetti, e le recentissime dettagli dal Cavaglier Sagramoso", G. Garampi do L.O. Pallaviciniego, Warszawa, 17 V 1775, AV, Segr. Stato, Polonia 316, k. 133v-134r.

7 G.A. Archetti do Stanisława Augusta, Rzym, 22 VII 1775, Bib. Civica A. Mai, Arch. Gamba, Scatola 3, fasc. 172, k. 1-2/172.

${ }^{8}$ G.A. Archetti do C. Archettiego, Rzym, 22 VII 1775, Bib. Civica A. Mai, Arch. Archetti, Lettere, Scatola 4, fasc. 31/ Lettere dell'anno 1775, s.f. 
ograniczały się wyłącznie do sfery urzędowej, z czasem dając nuncjuszowi poczucie, iż cieszy się zaufaniem króla. Papieski dyplomata miał dostęp do króla co niedzielę, podczas oficjalnych audiencji. W miarę potrzeb mógł zawsze ubiegać się o audiencję prywatną. Poza nielicznymi sytuacjami konfliktowymi Stanisław August okazywał Archettiemu dużo życzliwej kurtuazji, a nawet dawał dowody przyjaźni. Ostatnim akordem tych relacji była ceremonia dekoracji biretem kardynalskim, 24 października 1784 r. w Grodnie, który to dzień król miał nazwać jednym z „najszczęśliwszych w życiu"'.

Oficjalne depesze nuncjusza do sekretariatu stanu odegrały istotną rolę w kreowaniu obrazu króla na dworze papieskim. Zachowana w Tajnym Archiwum Watykańskim korespondencja z lat 1776-1784 jest kompletna, zarówno co do oryginałów, jak i tzw. „registrów”, czyli ksiąg, do których listy były wpisywane in extenso, razem z załącznikami ${ }^{10}$. Depesze, z niewielkimi wyjątkami, pisane były w rytmie tygodniowym, w języku włoskim, a ich adresatem był sekretarz stanu papieża Piusa VI, kard. Lazzaro Opitio Pallavicini. Otrzymywał on relacje po trzech tygodniach od daty nadania - pełny cykl korespondencji obejmował półtora miesiąca. Historycy polscy i zagraniczni niejednokrotnie sięgali już do tych materiałów, by wymienić prace Macieja Loreta, Łukasza Kurdybachy czy Larry'ego Wolffa ${ }^{11}$. Okres nuncjatury Archettiego nie doczekał się jednak dotąd monografii i wciąż pozwala na źródłowe badanie pewnych wartych uwzględnienia zagadnień szczegółowych. Kwestia „obrazu

${ }^{9}$ F. Guglielmi do L.O. Pallaviciniego, 30 X 1784, Biblioteca Apostolica Vaticana, Vat. lat. 8338, k. 137v. List opublikowany w: M.J. Rouët de Journel, Nonciatures de Russie d'après les documents authentiques, vol. 1: Nonciature d'Archetti 1783-1784, Città del Vaticano 1952, s. 434-436. Zob. P. Zając, „Jeden z najszczęśliwszych dni króla Stanisława Augusta”Grodno, 24 października 1784 r., w: W cieniu wojen i rozbiorów. Studia z dziejów Rzeczypospolitej XVIII i początków XIX wieku, red. U. Kosińska, D. Dukwicz, A. Danilczyk, Warszawa 2014, s. $311 \mathrm{nn}$.

${ }^{10}$ Oryginały listów nuncjusza znajdują się w tomach opatrzonych następującymi sygnaturami: AV, Segr. Stato, Polonia, 317, 318, 319, 320, 321, 322, 323, 324, 325, 326, 327, 328, 329. Odpowiadają im registry AV, Segr. Stato, Polonia, 331, 332, 333, 334, 335, 336, 338, 371 oraz AV, Archivio della Nunziatura di Varsavia (dalej: Nunz. Varsavia), 60, 61, 62, 63, 64, 65. Dla uzyskania kompletu źródeł należy zajrzeć także do tzw. Additamenta, AV, Segr. Stato, Polonia, Add. t. 19, 21 i 22. Archiwalia te w formie mikrofilmów znajdują się w zbiorach Papieskiego Instytutu Studiów Kościelnych w Rzymie oraz w Punkcie Konsultacyjnym tegoż Instytutu w Warszawie, kopie mikrofilmów zostały przekazane także do placówki Ośrodka Archiwów, Bibliotek i Muzeów Kościelnych w Lublinie.

11 Zob. M. Loret, Kościót katolicki a Katarzyna II, 1772-1784, Kraków-Warszawa 1910; Ł. Kurdybacha, Dzieje Kodeksu Andrzeja Zamoyskiego, Kraków 1951; L. Wolff, The Vatican and Poland in the Age of the Partitions. Diplomatic and Cultural Encounters at the Warsaw Nunciature, New York 1988. Są to jedynie przykłady znacznie obszerniejszej bibliografii. 
króla" jest jedną z takich właśnie spraw i może stanowić przyczynek do lepszego poznania zabiegów Stanisława Augusta o kreowanie pozytywnego wizerunku własnego i Rzeczypospolitej na europejskich dworach. Już M. Loret stwierdzał: „Stosunek Watykanu do dworu warszawskiego od samego początku panowania Stanisława Augusta nie najlepszy, pełen obustronnych podejrzeń, [--] pogorszył się znacznie, a nawet groził zupełnym zerwaniem z chwilą, gdy po łagodnym i układnym nuncjuszu Viscontim objął posterunek warszawski Anioł Maria Durini"12. O negatywnym postrzeganiu króla przez nuncjuszy papieskich, a nawet ,innych dyplomatów akredytowanych w stolicy" wspomina się i w nowszych publikacjach ${ }^{13}$. W tym kontekście warto zastanowić się nad stanowiskiem Archettiego, który był widywany na ulicach Warszawy od kwietnia $1776 \mathrm{r}$. do maja 1783 r. oraz krótko jesienią 1784 r., po powrocie z Petersburga i przed definitywnym opuszczeniem Rzeczypospolitej.

Do pierwszego spotkania Stanisława Augusta z Archettim doszło w poniedziałek 29 kwietnia $1776 \mathrm{r}^{14} \mathrm{~W}$ audiencji na Zamku Królewskim w Warszawie uczestniczył także ustępujący nuncjusz, Garampi. Archetti wręczył polskiemu władcy brewe Piusa VI oraz list sekretarza stanu, kard. Pallaviciniego. Ustnie przekazał wyrazy papieskiej życzliwości dla króla oraz współczucia z powodu okoliczności, w jakich znalazła się Rzeczpospolita („nelle presenti circostanze di questo Regno”). Papież wyrażał nadzieję na to, że nadejdą lepsze czasy, w których gorliwość króla i pobożność narodu poskutkuje zaleczeniem ran zadanych państwu i Kościołowi katolickiemu ${ }^{15}$. Były to sformułowania ogólne, bez żadnych konsekwencji natury politycznej czy prawnej - instrukcja sekretariatu stanu dla Archettiego zalecała szczególną rozwagę w traktowaniu zagadnień związanych z nowymi nabytkami Rosji i Prus oraz całkowicie zakazywała podejmowania kwestii zaboru austriackiego ${ }^{16}$. Zastrzeżenia te wynikały przede wszystkim z troski o status katolicyzmu w Rzeczypospolitej oraz o los katolików pod berłami zaborców protestanckiego

12 M. Loret, Zamach na Stanisława Augusta, s. 547-548.

13 W. Kęder, op. cit., s. 299.

${ }^{14}$ G.A. Archetti do L.O. Pallaviciniego, 1 V 1776, AV, Segr. Stato, Polonia 327, k. 41rv. Cf. ANP 54/1, N. 153.

15 „inestimabile era il dolore che [il Santo Padre] provava nelle presenti circostanze di questo Regno, ma che tuttavia lo rincorava una giusta speranza che alfin spuntati sarebbero tempi più favorevoli, in cui né allo zelo di Sua Maestà, né alla pietà di una si Religiosa Nazione mancar potrebbero mezzi efficaci per risaldare le piaghe passate, e per ristabilire la Religione ne' suoi antichi diritti", ibidem.

${ }^{16}$ Istruzione della Segreteria dello Stato per Mons. Archetti, Roma, 31 X 1775, AV, Nunz. Varsavia 100, k. 10r-30r; ANP 54/1, N. 68. 
i prawosławnego. Stanisław August w odpowiedzi przywołał Garampiego na świadka swej troski o dobro kraju i pomyślność wyznania panującego. W podobnej poetyce utrzymana była uroczysta publiczna audiencja, którą zwyczajem poprzedników Archetti odbył 24 września 1776 r., przypominając o swej misji obrońcy katolicyzmu, praw Kościoła i duchowieństwa w Rzeczypospolitej ${ }^{17}$.

W kolejnych latach konwencjonalne grzeczności nieustannie towarzyszyły obu stronom, nawet jeśli w danej sprawie zdania były rozbieżne. Okazją do pierwszej konfrontacji poglądów stała się sprawa możliwości wyboru dysydenckiego posła na sejmiku we Wschowie ${ }^{18} .19$ maja 1776 r., podczas cotygodniowej niedzielnej audiencji, Archetti domagał się od króla zdecydowanego przeciwdziałania mandatowi dla innowiercy, król zaś tłumaczył konieczność zajęcia bardziej dyskretnego i wyważonego stanowiska, by nie wywoływać rozdrażnienia Rosji. Obiecywał, iż będzie starał się ograniczać poparcie obcych mocarstw na rzecz dysydentów, ale musi czynić to rozważnie i stopniowo ${ }^{19}$. Archetti przekonał się, że w tym przypadku realnej pomocy nie udzielą mu ani król, ani kanclerz wielki koronny, bp Andrzej Młodziejowski, ani ambasador austriacki w Warszawie, Karl Reviczky. Nuncjusz postanowił więc zmobilizować wielkopolską szlachtę do skutecznego poparcia katolickiego kandydata ${ }^{20}$. Pomimo rezerwy wobec poczynań nuncjusza król je tolerował i życzył mu powodzenia, a po otrzymaniu wiadomości o przebiegu sejmików i wyborze we Wschowie katolika, okazał satysfakcję ${ }^{21}$. Zapewniał też, że podczas sejmu nie dopuści do dalszych ustępstw na rzecz dysydentów, o czym nuncjusz donosił sekretarzowi stanu jeszcze w depeszy z 10 lipca. Podsumowując

17 G.A. Archetti do L.O. Pallaviciniego, 25 IX 1776, AV, Nunz. Varsavia 60, k. 67r-v. Przemówienie Archettiego do króla, k. 68r-v.

18 Por. J. Michalski, Sprawa wyboru posłów dysydentów na sejm 1776 roku, w: Kultura staropolska - kultura europejska. Prace ofiarowane Januszowi Tazbirowi w siedemdziesiata rocznice urodzin, red. S. Bylina i in., Warszawa 1997, s. 273-280. W przeciwieństwie do studium Michalskiego opartego na szerokiej kwerendzie, wyłącznie na podstawie depesz nuncjusza i sekretariatu stanu sprawę tę omawia L. Wolff, op. cit., s. $118 \mathrm{nn}$.

19 G.A. Archetti do L.O. Pallaviciniego, 22 V 1776, AV, Segr. Stato, Polonia 317, k. 278r, 280v-281r; ANP 54/1, N. 200.

${ }^{20}$ Jedynym świadectwem tego zaangażowania zachowanym w oficjalnej dokumentacji nuncjatury jest kopia listu Archettiego z 15 czerwca 1776 r. do nieoznaczonego adresata. Z treści wynika, że mógł nim być kanonik gnieźnieński Michał Lipski. Nuncjusz, powołując się na chwalebną przeszłość rodziny Lipskich, sugeruje mu, by skłonił swego brata, Ignacego, łowczego wschowskiego, do wystawienia swej kandydatury na sejmiku we Wschowie. AV, Nunz. Varsavia 19, k. 397r-v, 401r-v. Zob. ANP 54/1, N. 288.

${ }^{21}$ G.A. Archetti do L.O. Pallaviciniego, 24 VII AV, Segr. Stato, Polonia 317, k. 413r; ANP 54/1, N. 443. 
owo pierwsze doświadczenie polityczne Archettiego w Rzeczypospolitej, trzeba stwierdzić, że choć zabrakło mu czynnego poparcia króla w okresie przedsejmikowym, nie przekazywał do kurii rzymskiej negatywnych opinii o polskim monarsze. Dostrzegając zależność Stanisława Augusta od Rosji, Archetti liczył jednak na jego inicjatywę i zaangażowanie, które pomogłyby pokrzyżować intencje rosyjskiego ambasadora ${ }^{22}$.

Jednym z żywo dyskutowanych tematów na sejmie 1776 r. była sprawa opodatkowania dóbr kościelnych. Duchownym zależało na zmniejszeniu wysokości subsidium charitativum, lecz nie zamierzano wysuwać tego postulatu w czasie obrad. Archetti rozmawiał na ten temat z bpem Michałem Jerzym Poniatowskim i obaj zgodzili się, że byłoby to niestosowne i ryzykowne ${ }^{23}$. Temat finansów duchowieństwa został jednak wywołany na sali sejmowej, wkrótce po ogłoszeniu przedłużenia obrad do 26 października. 3 października kasztelan przemęcki, Rafał Gurowski, wygłosił mowę, w której skrytykował projekt „Cywilnej tabeli ekspensy generalnej przez J.O. Książęcia Biskupa Wileńskiego podanego" ${ }^{24}$. Przechodząc do kwestii wydatków na wojsko, stwierdzał, że stan świecki jest już nadmiernie udręczony podatkami i duchowni powinni wziąć na siebie poważniejszą część tych ciężarów. Powołał się na przykłady uchwalania subsidium charitativum w latach 1527, 1578, 1676 i 1717 oraz uskarżał na to, że biskupi od „lat wspomnionych nie posiłkują stanu naszego”. Dodawał: „I tymże się tylko ma różnić Prześwietny Stan Duchowny, aby się od sprawiedliwej wyłączali daniny z uszczęśliwieniem siebie, a najoczywistszym

${ }^{22}$ Wolff, cytując depesze Archettiego, dostrzega głównego reżysera istotnych wydarzeń politycznych w Rzeczypospolitej wyłącznie w Ottonie Magnusie Stackelbergu; królowi pozostawia jedynie rolę łącznika między rosyjskim ambasadorem a nuncjuszem. Czyni tak, np. nawiązując do listu Archettiego do Pallaviciniego z 10 lipca 1776 r., AV, Segr. Stato, Polonia 317, k. 374r-v (ANP 54/1, N. 386), w którym mowa o kwestii dysydentów w kontekście przygotowań do sejmu 1776 r. Wolff przekazuje tę wiadomość w słowach: „By July Stackelberg was not only willing to permit the Protestant majority at Fraustadt to be upset, but he was even ready to convey to Archetti, through the King, an assurance that Dissident privileges would not be extended at the coming Sejm", L. Wolff, op. cit, s. 122. Cytowany fragment nie dostarcza jednak dowodów, by to Stackelberg coś przekazywał nuncjuszowi za pośrednictwem króla. Innego zaś źródła, które mogłoby taką informację potwierdzać, Wolff nie cytuje.

${ }^{23}$ Zdaniem nuncjusza, zamiast manifestować troskę o dobra ziemskie, należało raczej walczyć o „vero bene sostanziale della Religione”, G.A. Archetti do L.O. Pallaviciniego, 4 IX 1776, AV, Nunz. Varsavia 60, k. 58v. Dalsze cytaty ze źródeł watykańskich będą nawiązywać do registrów.

${ }^{24}$ Mowa J.W. JMCI Pana Gurowskiego kasztelana przemęckiego w senacie dnia 3. października roku 1776 miana, w: Zbiór mów różnych w czasie dwóch seymów ostatnich roku 1775 y 1776 mianych, t. 3: Mowy w czasie Seymu Ordynaryinego Roku 1776 od 20 dnia września do końca seymu, Poznań 1777, s. 165-173. 
Stanu Szlacheckiego uciemiężeniem?”, kończąc postulatem: „Gdy zaś czopowe z miast i wsiów rozciągnie się, i kwarta na dobra, ale szczególnie same duchowne, jakom wyraził, upraszać W.K.Mci mam za powinność o wyznaczenie lustratorów, a w tym przybędzie do Skarbu; a zubożały Stan Świecki przynajmniej z poddaństwem swoim odetchnie przez dwa lata, i wielka będzie wspaniałość Stanu Duchownego"25.

Zgodnie z relacją Archettiego postulat zmierzał do zwiększenia dochodów publicznych przez nałożenie dwudziestopięcioprocentowego podatku na wszystkie dobra biskupie, opactwa i prepozytury należące do nominacji królewskiej.

Król zgłosił sprzeciw ${ }^{26}$, za co po zakończeniu dnia obrad żywo dziękowali mu biskupi i nuncjusz ${ }^{27}$. Sprawa nie była jednak zamknięta. Wedle relacji Archettiego Gurowski następnego dnia zaatakował marszałka sejmu, Andrzeja Mokronowskiego, za to, że jego projekt nie został dostarczony wszystkim posłom. Trudno określić, w jakim stopniu Archetti był świadom, iż działanie Gurowskiego, należącego na sejmie 1776 r. do opozycji, było ostrą formą polemiki z propozycjami podatków zgłaszanymi przez stronnictwo królewskie i wpisywało się w całość debaty nad finansami państwa, w której zagadnienie dóbr duchownych nie stanowiło kwestii

25 Ibidem, s. 170-171, pełny tekst propozycji Gurowskiego s. 172-173. Biogram Gurowskiego w PSB nie wspomina o tej jego inicjatywie na sejmie 1776 r. Zob. J. Wisłocki, Gurowski Rafał h. Wczele (1716-1797), PSB, t. 9, Wrocław 1961, s. 170-171.

${ }^{26} \mathrm{Na}$ zakończenie sesji 3 października Stanisław August odniósł się do całodniowej dyskusji, w tym do propozycji R. Gurowskiego: „Drugi projekt podany od tegoż senatora względem kwarty z dóbr duchownych, wiem, że z czystego pochodzi powodu, to jest z miłości i ochrony obywatelów świeckich; ale że nie godzi się nigdy uchylać względów dla sprawiedliwości, muszę powiedzieć, że lubo słyszałem nieraz zdania, że stan duchowny jest zbyt ochroniony, a stan świecki przeładowany ciężarami, a zatym, że potrzeba, aby duchowny poniósł osobne podatki; lubo mówię, słyszałem te zdania, ale przychylić się do nich nie mogę, bo wiem, że dobra duchowne równo z ziemskiemi wszystkie ponoszą publiczne ciężary, a prócz tych dobrowolnie Jchmość Xięża Biskupi przyjęli na się onus doni gratuiti na przeszłym sejmie, co sami przewielebni biskupi dokładniej wyłuszczyć potrafią, gdy tego będzie potrzeba", Diariusz sejmu ordynaryjnego pod związiem konfederacyi generalnej Obojga Narodów agitującego się, Warszawa 1776, s. $225-226$.

${ }^{27}$ Nuncjusz dodatkowo skrytykował Gurowskiego: „Il Gurowski è uno di quegl'uomini arditi, impetuosi, ostinati, che servono alle buone e alle cattive cause secondo riesce al più scaltro di guadagnarli", G.A. Archetti do L.O. Pallaviciniego, 9 X 1776, AV, Nunz. Varsavia 60, k. 75v. W innych źródłach Gurowski przedstawiany jest jednak jako człowiek religijny, autor epitafiów nagrobnych, dobrodziej szeregu klasztorów i kościołów wielkopolskich. Zob. S. Sterna-Wachowiak, Rafał Gurowski - starosta Wschowy, „Przyjaciel Ludu” 1988, z. 3, s. 10-13. Gurowski jako dobrodziej Kościoła występuje też w tomie: Rafał hrabia Gurowski. Szkice do XVIII-wiecznego portretu szlacheckiego, red. K. Lutowski, M. Małkus, Wschowa 2007. 
najważniejszej ${ }^{28}$. W swych pamiętnikach Stanisław August umieścił postulat kasztelana przemęckiego w tym właśnie kontekście szerszej dyskusji ${ }^{29}$. Kolejne dni upłynęły nuncjuszowi na rozmowach i zabiegach zmierzających do tego, by nie dopuścić do formalnego zgłoszenia projektu kasztelana przemęckiego. Zapewne jednak nie tyle staraniom nuncjusza, ile inicjatywie Stanisława Augusta przypisać należy fakt, iż przechodząc do dalszej debaty nad finansami publicznymi, pominięto kwestię podatku z dóbr duchownych ${ }^{30}$. Jedynym efektem pierwotnej dyskusji było późniejsze milczenie biskupów w sprawie papieru stemplowego, za który opłaty miały obowiązywać także kancelarie kościelne. Archetti stwierdził, że wizja powrotu projektu Gurowskiego tak przestraszyła biskupów, iż poniechali obrony autonomii kancelarii kościelnych ${ }^{31}$.

Kolejnym testem stanowiska króla w kwestiach kościelnych stało się zagadnienie minimalnego wieku dla złożenia profesji zakonnej - typowy postulat reform oświeceniowych wprowadzanych przez dwory europejskie $^{32}$. Echa tych reform docierały także nad Wisłę. Sejm 1768 r. podjął decyzję o podniesieniu minimalnego wieku dla profesji zakonnej do 24 lat w przypadku mężczyzn i 16 lat w przypadku kobiet ${ }^{33}$, lecz prawo to pozostawało martwą literą. Archetti nie został o tym uprzedzony w instrukcji sekretariatu stanu, dlatego był zaskoczony, gdy podczas pierwszego spotkania z kanclerzem Młodziejowskim usłyszał o konieczności wyegzekwowania wspomnianej konstytucji. Minister oczekiwał od nuncjusza podjęcia starań o papieską aprobatę dla decyzji sejmowej i uprzedzał, że przy jej braku Rada Nieustająca może podjąć decyzje wykonawcze bez zwracania uwagi na stronę kościelną. Zaskoczony Archetti odmawiał sejmowi kompetencji w tego rodzaju spawach, powołując się na dekrety Soboru Trydenckiego. Po przebadaniu dokumentacji swego poprzednika stwierdził, że Garampi przekazał do Rzymu rządowy postulat papieskiej aprobaty dla ustawy z 1768 r., ale jednocześnie sugerował, by odwlekać decyzję, aż sprawa ucichnie ${ }^{34}$.

${ }^{28}$ Zob. A. Stroynowski, Opozycja sejmowa w dobie rządów Rady Nieustajacej. Studium z dziejów kultury politycznej, Łódź 2005, s. 31, 432.

29 Stanislas Auguste, Mémoires, wyd. A. Grześkowiak-Krwawicz, D. Triaire, Paris 2012, s. 627.

${ }^{30}$ G.A. Archetti do L.O. Pallaviciniego, 9 X 1776, AV, Nunz. Varsavia 60, k. 75v-76r; Stanislas Auguste, Mémoires, s. $633 \mathrm{nn}$.

${ }^{31}$ VL 8, s. 889. G.A. Archetti do L.O. Pallaviciniego, 16 X 1776, AV, Nunz. Varsavia 60, k. $78 \mathrm{v}-79 \mathrm{r}$.

32 Zob. F. Venturi, Settecento riformatore, t. 2: La chiesa e la repubblica dentro i loro limiti, 1758-1774, Torino 1976, s. 90-91.

33 VL 7, s. 745.

34 G.A. Archetti do L.O. Pallaviciniego, 15 V 1776, AV, Segr. Stato, Polonia 317, k. 263r-267r. 
Ponowienie polskich żądań wywołało poruszenie w sekretariacie stanu ${ }^{35}$. Choć Młodziejowski przez kolejne miesiące nie powracał do tematu, w Rzymie przygotowano brewe, w którym Pius VI wzywał króla do obrony zasad życia zakonnego w Rzeczypospolitej ${ }^{36}$. Zostało ono wręczone królowi 14 sierpnia w Łazienkach. Stanisław August stwierdził, że ustawy sejmu z 1768 r. łatwo odwołać się nie da, ale uczyni wszystko, aby nie doszło do jej wykonania. Deklarował, że osobiście darzy zakonników szacunkiem, zwłaszcza pijarów i teatynów - w domyśle jako zakony czynne, oddane dziełu edukacji ${ }^{37}$. Nie najlepsze zdanie miał natomiast o zakonach kontemplacyjnych i żebraczych, których klasztory, jak twierdził, były przeludnione oraz oskarżane o słaby poziom wykształcenia i brak zakonnej dyscypliny. Stanisław August argumentował, iż zakony żebracze mają nieraz po kilka klasztorów w miastach lub w ich pobliżu i są zbędne tam, gdzie liczba duchownych prowadzących regularne duszpasterstwo jest wystarczająca. Troską króla była ponadto mała gęstość zaludnienia kraju, kontrastująca z liczebnością niektórych zakonów ${ }^{38}$. Pomimo kontrargumentacji nuncjusza Stanisław August nie zmienił zdania i na sejmie 1776 r. nie mogło być mowy o złagodzeniu konstytucji sejmowej $1768 \mathrm{r}^{39}$ Kanclerz Młodziejowski zapewnił jedynie Archettiego, że dołoży starań, by jej nadal nie egzekwowano. Do końca 1776 r. nie powrócono już do tego tematu.

Niezależnie od opisanych wyżej dyskusji stwierdzić trzeba, iż w dobie sejmu 1776 r. sprawy kościelne nie należały do głównego nurtu zainteresowań Stanisława Augusta. Nuncjusz przedstawiał polskiego króla jako

35 L.O. Pallavicini do G.A. Archettiego, 9 VI 1776, AV, Nunz. Varsavia 46, k. 80r-82r.

${ }^{36}$ Brewe przesłane wraz z depeszą z 13 lipca 1776 r. nosiło tę samą datę, zob. AV, Epistolae ad Principes 176, k. 109v-113r. Nuncjusz otrzymał kopię dzieła Analisi critica del trattato del signor Levayer de Boutigny: Dell'autorità del Re sopra l'età necessaria alla professione solenne de' Religiosi (del P. Ermanno Domenico Cristianopulo, domenicano), b.m.w., 1772 , t. 2. Traktat, o którym mowa w tytule tego dzieła apologetycznego, opublikowano po raz pierwszy w 1669 r.: De l'autorité du roy touchant l'âge nécessaire à la Profession solemnelle des Religieux, Paris 1669. Tłumaczenie włoskie ukazało się w Wenecji w 1768 r.: Dell'autorità del re sopra l'età necessaria alla professione solenne de' religiosi. Opera del signor Le Vayer de Butigni' [sic!], avvocato del Parlamento di Parigi, ed ora trasportata in Lingua Italiana, Venezia 1768.

37 Te zakony król wymienił z nazwy. Nuncjusz zaś, omawiając stanowisko monarchy w korespondencji z sekretarzem stanu, dodał do tej listy jeszcze bazylianów, misjonarzy, bonifratrów i mercedariuszy, jako zakony przez Stanisława Augusta akceptowane. G.A. Archetti do L.O. Pallaviciniego, 21 VIII 1776, AV, Nunz. Varsavia 60, k. $47 \mathrm{v}-48 \mathrm{r}$.

${ }^{38}$ Ibidem. Argumentacja typowa dla myślenia oświeceniowego, w rozroście liczebnym zakonów upatrująca zagrożenie dla demograficznego rozwoju społeczeństwa.

39 G.A. Archetti do L.O. Pallaviciniego, 30 X 1776, AV, Nunz. Varsavia 60, k. 89v. 
synowsko oddanego Piusowi VI, ale przekazywał też sekretarzowi stanu opinie o jego malejącym autorytecie:

Trudno dostatecznie wyrazić, jak dalece z każdym dniem król traci w oczach narodu na skutek rezultatu ostatniego sejmu. Rozbiór, całkowity upadek handlu krajowego, pobyt wojsk rosyjskich, nowe obciążenia, pozbawienie możliwości gratyfikowania rozdawnictwem starostw, jego źle ukierunkowane prywatne wydatki, nadmierne wydatki, dotkliwy brak pieniędzy, zaciągnięte długi, wreszcie charakter jego mężów zaufania, wszystko to pozbawiło go przywiązania [poddanych $]^{40}$.

Zdaniem Archettiego obecność militarna Rosji dawała królowi poczucie bezpieczeństwa, lecz była dlań zarówno wsparciem, jak i kajdanami (,il suo sostegno e la sua catena”) ${ }^{41}$. Archetti dostrzegał zależność króla od Rosji, jednak widział także jego wysiłki emancypacyjne. Latem 1776 r. Stanisław August, zachęcony zgodą Rosji na reformę Rady Nieustającej na zbliżającym się sejmie, poprosił Ottona Magnusa Stackelberga o poparcie przed Katarzyną II projektu zwiększenia kompetencji króla w doborze członków Rady. Pragnął także zgody na to, by sejm skonfederowany 1776 r. nie został rozwiązany, lecz by zachował w ograniczonej formie zdolność ustawodawczą. Dla Stackelberga były to propozycje nie do przyjęcia $^{42}$. Nuncjusz, który dopiero niedawno uświadomił sobie, iż to Rosja, a nie Austria, jest faktycznym arbitrem polskich spraw, pokusił się o komentarz: „[Król] nie potrafi się pogodzić z faktem, że caryca pragnie, by Rzeczpospolita była spokojna, ale słaba, a jego chce utrzymywać na tronie, ale nie czynić władcą absolutnym"43.

Początek roku 1777 przyniósł pierwszy poważny kryzys w relacjach króla z nuncjuszem, związany ze wznowieniem starań monarchy o objęcie

40 „Dopo l'esito dell'ultima Dieta non si può ridire abbastanza quanto il Re sia andato di giorno in giorno scapitando appresso la Nazione. Il partaggio, la rovina totale del commercio interno, il soggiorno delle truppe Russe, le nuove gravezze, il non poter più beneficare colle starostie, le sue private liberalità mal collocate, le spese eccessive, la penuria somma di danaro, e i debiti contrati, le qualità finalmente dei suoi medesimi confidenti gli anno scemata l'affezione", G.A. Archetti do L.O. Pallaviciniego, 28 VIII 1776, AV, Nunz. Varsavia 60, k. 51v. Tłum. w całym artykule moje, P.Z.

${ }^{41}$ G.A. Archetti do L.O. Pallaviciniego, 4 IX 1776, AV, Nunz. Varsavia 60, k. 57v.

${ }^{42}$ Zob. J. Michalski, Dwie misje księcia Stanisława, w: idem, Studia historyczne z XVIII i XIX wieku, t. 1: Polityka i społeczeństwo, red. W. Kriegseisen, Z. Zielińska, Warszawa 2007, s. $376-378$.

${ }^{43}$ „[Il Re] non sa in tutti i momenti persuadersi che la Czara vuole quieto questo Regno, ma non potente, e vuole sostener lui sul trono, ma non renderlo assoluto", G.A. Archetti do L.O. Pallaviciniego, 4 IX 1776, AV, Nunz. Varsavia 60, k. 65v. 
kolejnych opactw w Rzeczypospolitej prawem komendy ${ }^{44}$. Po utracie na sejmie rozbiorowym prerogatywy rozdawnictwa starostw oraz zaborze opactwa tynieckiego przez Austrię sprawa przejęcia kolejnych opactw in commendam stała się dla Stanisława Augusta pilna. Rzecz poruszono po raz pierwszy w 1775 r., w okresie nuncjatury Garampiego. Ten przed wyjazdem nie zdołał zebrać potrzebnych Stolicy Apostolskiej informacji, a w instrukcji sekretariatu stanu nowy nuncjusz otrzymał polecenie, aby przyjąć postawę wyczekiwania, nie podejmując tematu, dopóki sam król doń nie powróci ${ }^{45}$. Stanisław August milczał do 2 lutego 1777 r. Na wieść o śmierci opata cystersów w Bledzewie, Franciszka Rogalińskiego, król i kanclerz Młodziejowski zwrócili się do Archettiego z prośbą o powstrzymanie zakonników od kanonicznego wyboru następcy. Bledzew był jednym z zasobniejszych opactw cysterskich i Stanisław August zamierzał natychmiast rozpocząć starania w Rzymie o włączenie go do kategorii opactw komendatoryjnych nominacji królewskiej ${ }^{46}$. Nuncjusz obiecał przekazać królewską prośbę Piusowi VI, ale odmówił ingerencji w kanoniczną procedurę wyboru opata przez zakonników, powołując się na brak stosownych uprawnień ${ }^{47}$. Stanisław August zakończył audiencję wyrazami nadziei, że jego prośba zostanie wysłuchana ${ }^{48}$. Stanowisko monarchy w pełni podzielał Gaetano Ghigiotti: należy powstrzymać wybór opata w Bledzewie, ponieważ w przeciwnym wypadku, nawet jeśli król otrzyma pozwolenie papieskie na przejęcie tego opactwa w komendę, z nominacją opata komendatoryjnego będzie trzeba czekać aż do śmierci opata wybranego drogą kanoniczną. Archetti, bojąc się radykalizacji stanowiska królewskiego, sugerował Ghigiottiemu nienaruszanie ustalonego porządku prawnego w nadziei, iż papież uwzględni królewskie racje, otrzymawszy oficjalną petycję ${ }^{49}$. Król początkowo ustąpił. 3 lutego

${ }^{44}$ Prerogatywy królewskie w tej materii zostały określone definitywnie w konkordacie wschowskim z 10 lipca 1737 r. Na jego mocy król miał prawo mianowania opatów komendatoryjnych w 13 opactwach: Tyńcu, Lubiniu, Płocku, Wąchocku, Mogile, Sulejowie, Wągrowcu, Jędrzejowie, Paradyżu, Czerwińsku, Trzemesznie, Hebdowie i Miechowie. Zob. T. Włodarczyk, Konkordaty. Zarys historii ze szczególnym uwzględnieniem XX wieku, t. 1, Warszawa 1986, s. 104-105. Zob. także J. Ostrowski, La Commende en Pologne et le Concordat de Wschowa en 1737, w: La Pologne au VII-e Congrès International des Sciences Historiques, t. 2, Varsovie 1933.

${ }^{45}$ Istruzione della Segreteria dello Stato per Mons. Archetti, Roma, 31 X 1775, AV, Nunz. Varsavia 100, k. 20v-21r; ANP 54/1, N. 68.

${ }^{46}$ G.A. Archetti do L.O. Pallaviciniego, 5 II 1777, AV, Segr. Stato, Polonia 332, k. 12r-13r.

${ }^{47}$ Ibidem, k. 13 r.

48 „Spero, che nulladimeno mi compiacerete in ciò, che vi dimando", ibidem, k. 13v.

49 „V.E. potrà comprendere quali in tutto quel giorno fossero le angustie e quale il timore, che il Re arbitro del Consiglio Permanente non prendesse qualche risoluzione 
obiecał Archettiemu, iż nie będzie krępował wolnego wyboru opata w Bledzewie ${ }^{50}$. Być może uspokoiło go złożone dzień wcześniej przez Archettiego zapewnienie, że papież, widząc szacunek króla dla praw kościelnych, odmówi potwierdzenia opata-elekta. 17 lutego nowym opatem bledzewskim został Onufry Wierzbiński, po miesiącu potwierdzony przez opata generalnego cystersów ${ }^{51}$. Wkrótce do analogicznej sytuacji doszło w opactwie cystersów w Lądzie. Po śmierci Konstantyna Iłowieckiego, 8 marca opatem wybrano Benedykta Lubstowskiego. Archetti podkreślał wobec swych zwierzchników, że król nie przeszkodził obu wyborom, zdając się w pełni na oficjalną drogę negocjacji z Rzymem ${ }^{52}$.

Przebieg wydarzeń nie spełnił nadziei Stanisława Augusta, ale szczegółowe ich zrelacjonowanie wykroczyłoby poza tematyczne ramy niniejszego artykułu. Wystarczy stwierdzić, iż z końcem kwietnia 1777 r. Stanisław August zaczął się niecierpliwić przedłużającym się milczeniem Rzymu i bezsilnie obserwował początki oficjalnych rządów kanonicznie wybranych opatów w Bledzewie i Lądzie ${ }^{53}$. Ponieważ papież skierował rozpatrzenie prośby królewskiej w sprawie opactw do kongregacji konsystorialnej, kardynał protektor Rzeczypospolitej zasugerował Archettiemu, iż warto postarać się o powtórzenie petycji w prywatnym piśmie Stanisława Augusta do Piusa VI ${ }^{54}$. Podczas audiencji 18 maja 1777 r. król zapowiedział Archettiemu, iż takie pismo zredaguje osobiście ${ }^{55}$. List polskiego monarchy został odczytany papieżowi 7 czerwca 1777 r. Reakcja Piusa VI była daleka od oczekiwań Warszawy. Papież kilka dni wcześniej potwierdził wybór opata Bledzewa ${ }^{56}$ - akta jego kanonicznej elekcji dotarły do Rzymu wcześniej niż przypominające o petycji pismo królewskie. Kard. Pallavicini sugerował nieoficjalnie, aby przekonać króla, że potwierdzenie opatów nie przeszkadza pozytywnemu rozpatrzeniu petycji monarchy w Stolicy Apostolskiej, trzeba jednak zgromadzić szczegółowe informacje

lesiva dell'Ecclesiastica immunità, scandalosa agli occhi di tutta la Nazione, e di pessimo esempio per altri simili casi in avvenire", ibidem, $14 \mathrm{v}$.

${ }^{50}$ Ibidem, k. 14r.

51 G.A. Archetti do L.O. Pallaviciniego, 5 III 1777, AV, Segr. Stato, Polonia 332, k. 26v. Uwierzytelniony odpis aktu elekcji kanonicznej opata (instrumentum electionis), sporządzony w Bledzewie z datą 18 II 1777, w Archiwum Państwowym w Poznaniu (dalej: APP), Cystersi Bledzew 140, s. 156-157; F. Trouvé do O. Wierzbińskiego, Citeaux, 17 III 1777, ibidem, s. 159.

52 G.A. Archetti do L.O. Pallaviciniego, 5 III 1777, AV, Segr. Stato, Polonia 332, k. 26v.

53 G.A. Archetti do L.O. Pallaviciniego, 30 IV 1777, AV, Segr. Stato, Polonia 332, k. 64r-v.

54 G.A. Archetti do L.O. Pallaviciniego, 14 V 1777, AV, Segr. Stato, Polonia 332, k. 71r.

55 G.A. Archetti do L.O. Pallaviciniego, 21 V 1777, AV, Segr. Stato, Polonia 332, k. 72v.

56 Opat bledzewski potwierdzony został przez Piusa VI 3 czerwca, opat Lądu 3 lipca 1777 r. Zob. Pius VI do G.A. Archettiego, 13 IX 1777, APP, Cystersi Bledzew 140, s. 163. 
na temat stanu majątkowego opactw ${ }^{57} .21$ czerwca dodatkowo wyjaśnił stanowisko Piusa VI w sposób zaprzeczający wcześniejszym zapewnieniom: w myśl litery prawa pozbawienie urzędu legalnie wybranego opata wymagałoby formalnego procesu kanonicznego, do którego nie było podstaw $^{58}$. Pozornie drobna kwestia proceduralna zaczęła urastać do rangi poważnego konfliktu. Według relacji Archettiego król poczuł się zlekceważony; żałował, że posłuchał rady nuncjusza i zamiast przeszkodzić w nominacji opata, oddał całą sprawę w ręce papieża ${ }^{59}$. Pożegnanie po audiencji 6 lipca było chłodne, Stanisław August zapowiedział podjęcie dalszych kroków ${ }^{60}$.

Był to początek najtrudniejszego okresu w relacjach nuncjusza z królem, o czym świadczą depesze Archettiego aż do września 1777 r. 8 lipca zredagowano w Radzie Nieustającej notę ministerialną do Piusa VI. Podnoszono w niej zlekceważenie królewskich próśb i zapowiadano dalsze kroki w kwestii opactw ${ }^{61}$. W Rzymie zapanowała konsternacja. Deklarowano, iż wbrew wrażeniu, jakie zrodziło się nad Wisłą, Pius VI nie zamierzał czynić afrontu Stanisławowi Augustowi i był zaskoczony skalą jego reakcji ${ }^{2}$. W relacjach króla z Archettim pojawił się dystans. Przy prezentacji bulli papieskiej w sprawie opactw, 3 sierpnia 1777 r., Stanisław August uprzedził nuncjusza, iż zna jej treść, a ponieważ nie spełnia ona królewskich oczekiwań, prywatna audiencja w celu dokładniejszego wyłożenia papieskich intencji nie jest konieczna ${ }^{63}$. W kolejnych tygodniach król rozważał dalsze kroki w sprawie klasztorów bez konsultowania Archettiego, który zdobywał potrzebne informacje „inną drogą"64. 9 sierpnia Stanisław August zwrócił się bezpośrednio do zakonników z Bledzewa, informując o powierzeniu tymczasowej administracji dóbr opackich biskupowi poznańskiemu. Wzywał także opata-elekta do wstrzymania procesu przejmowania tychże dóbr:

57 L.O. Pallavicini do G.A. Archettiego, 7 VI 1777, AV, Segr. Stato, Polonia 337, k. 78v.

${ }^{58}$ L.O. Pallavicini do G.A. Archettiego, 21 VI 1777, AV, Segr. Stato, Polonia 337, k. 79r.

59 G.A. Archetti do L.O. Pallaviciniego, 9 VII 1777, AV, Segr. Stato, Polonia 332, k. 106v-107r.

${ }^{60}$ Ibidem, k. 107v.

${ }^{61}$ Swoista groźba brzmiała następująco: „comme néanmoins il n’a été fait aucune attention à la lettre que S.M. a écrite elle même au S. Père sur ce sujet, la Cour de Rome ne pourra imputer qu'à elle même les résolutions qu'on sera obligé de prendre", Note, Varsovie, 8 VII 1777, AV, Segr. Stato, Polonia 332, k. 109r-v.

${ }^{62}$ L.O. Pallavicini do G.A. Archettiego, 2 VIII 1777, AV, Segr. Stato, Polonia 337, k. $86 \mathrm{v}$.

${ }^{63}$ G.A. Archetti do L.O. Pallaviciniego, 6 VIII 1777, AV, Segr. Stato, Polonia 332, k. 126r.

${ }^{64}$ Nuncjusz nie ujawniał w relacjach, kto był jego informatorem. Zob. G.A. Archetti do L.O. Pallaviciniego, 27 VIII 1777, AV, Segr. Stato, Polonia 332, k. 141r. 
dobra stołu opackiego przewielebnemu w Bogu biskupowi poznańskiemu wziąć w administracją [--] zlecamy, a Wielebności, i Pobożnościom Waszym o tej woli naszej donosząc rozkazujemy, żebyście za rekwizycją przewielebnego biskupa poznańskiego lub z ramienia jego administratora do rzeczonych dóbr wyznaczonego, też dobra w administracją bez żadnego przeciwieństwa oddali i Wielebny Elekt konfirmacyi swojej uskutecznić nie domagał się, póki do tego naszego królewskiego przychylenia się mieć nie będzie ${ }^{65}$.

Ponieważ zakonnicy sprzeciwili się próbie przejęcia kontroli nad klasztorem przez komisarza biskupa poznańskiego, pojawiła się - wedle świadectwa Archettiego - groźba użycia przeciw opornym siły zbrojnej ${ }^{66}$. Stolica Apostolska zdążyła jednak z kompromisowym załatwieniem sprawy. 27 sierpnia 1777 r. Archetti otrzymał depeszę z uprawnieniem do zawieszania w przyszłości kanonicznych wyborów opatów w klasztorach, które mogłyby nadawać się do komendy królewskiej ${ }^{67}$. To ustępstwo Rzymu nie zadowoliło jednak Warszawy; Stanisław August podkreślił, iż zależy mu nie na przyszłych decyzjach, ale na aktualnym statusie Bledzewa i Lądu ${ }^{68} .3$ września nadszedł kolejny list kard. Pallaviciniego; nuncjuszowi zezwalano na wydanie formalnego, choć przejściowego (interinamente) zakazu objęcia dóbr opackich przez opatów Bledzewa i Lądu, byle tylko wycofane zostały królewskie postanowienia godzące w autorytet Stolicy Apostolskiej i zasady prawa kanonicznego ${ }^{69}$. Wiadomość przyszła w samą porę; jak donosił Archetti, wojsko właśnie otrzymało rozkazy siłowego udaremnienia przejęcia przez opatów dóbr Bledzewa i Lądu ${ }^{70}$.

Nuncjusz pośpieszył 5 września do Puław, zaskakując tym króla przygotowującego się do uroczystości rocznicy elekcji. W sobotę 6 września przedłożył mu propozycję Stolicy Apostolskiej, która tym razem usatysfakcjonowała Stanisława Augusta i poskutkowała natychmiastowym

${ }^{65}$ Stanisław August Poniatowski do cystersów w Bledzewie, APP, Cystersi Bledzew 135, s. 345.

${ }^{66}$ G.A. Archetti do L.O. Pallaviciniego, 27 VIII 1777, AV, Segr. Stato, Polonia 332, k. $140 \mathrm{v}$.

${ }^{67}$ L.O. Pallavicini do G.A. Archettiego, 2 VIII 1777, AV, Segr. Stato, Polonia 337, k. 87v. Papież podjął taką decyzję przed 5 lipca 1777 r. Zob. ibidem, k. 81v.

${ }^{68}$ G.A. Archetti do L.O. Pallaviciniego, 27 VIII 1777, AV, Segr. Stato, Polonia 332, k. 141r.

${ }^{69}$ L.O. Pallavicini do G.A. Archettiego, 13 VIII 1777, AV, Segr. Stato, Polonia 337, k. $91 \mathrm{r}-\mathrm{v}$.

70 Poszukiwania śladów tego rozkazu nie przyniosły rezultatu. Kwerendą objęto w AGAD zespoły: Militaria z Jabłonny, sygn. 35 i 38, Zbiór Popielów, sygn. 166, 167 i 223 , Metryka Litewska, sygn. VII 459 i VII 79. Podobnie negatywny wynik przyniosła kwerenda w Archiwum Młynowskim Chodkiewiczów (Archiwum Narodowe w Krakowie), sygn. 1122, 1133-1136, 1140-1144, 1150, 1156, 1162, 1164, 1168. 
odwołaniem wydanych wojsku rozkazów ${ }^{71}$. Dzień później nuncjusz zredagował w obecności monarchy stosowne polecenie do cystersów w Lądzie i Bledzewie, zawieszające opacką kontrolę nad dobrami klasztornymi ${ }^{72}$.

13 września 1777 r. Pius VI wystosował do Archettiego pismo, w którym podsumowywał całą sprawę, podkreślając, że choć potwierdził opatów Bledzewa i Lądu w czerwcu i lipcu tegoż roku, to świadom trwających pertraktacji ze Stanisławem Augustem, nie wysłał żadnemu $\mathrm{z}$ nich stosownej bulli. Tym samym dawał pośrednio do zrozumienia, że zaognienie sytuacji, do jakiego doszło latem, było nieuzasadnione. Polecał też Archettiemu dopilnowanie formalnego procesu rozdziału dóbr opackich na część klasztorną i opacką (należną opatowi komendatoryjnemu), zalecając zakonnikom całkowite posłuszeństwo Stolicy Apostolskiej, która przychyla się do królewskiego postulatu przejęcia opactw w komendę ${ }^{73}$. Archetti skierował do cystersów stosowne pismo 25 października $1777 \mathrm{r}^{74}$, dwa dni później król mianował opatem komendatoryjnym Bledzewa kard. F. Albaniego, protektora Rzeczypospolitej. Wyznaczeni przez króla komisarze duchowni mieli zająć się inwentaryzacją dochodów klasztoru ${ }^{75}$. Opatem komendatoryjnym Lądu został prymas Antoni Ostrowski ${ }^{76}$. Zakonnicy boleli nad utratą swych opactw („de amissione et perditione abbatiarum Landensis et Bledzoviensis"77), Archetti natomiast powrócił do pełni królewskich łask. Ośmielił się nawet wystosować „delikatne upomnienie” („un modesto rimprovero”) pod adresem Stanisława Augusta, za jego wcześniejsze zwątpienie co do

${ }^{71}$ G.A. Archetti do L.O. Pallaviciniego, 10 IX 1777, AV, Segr. Stato, Polonia 332, k. $148 \mathrm{r}$.

${ }^{72}$ Ibidem, k. 148v.

73 Pius VI do G.A. Archettiego, 13 IX 1777, APP, Cystersi Bledzew 140, s. 163.

${ }^{74}$ G.A. Archetti do cystersów w Bledzewie, 25 X 1777, APP, Cystersi Bledzew 125, s. $115-117$.

75 Proporcje podziału dóbr opactw komendatoryjnych określał art. 3 konkordatu wschowskiego, zob. T. Włodarczyk, op. cit., s. 102-103. Zob. Deklaracja królewskich komisarzy, Wojciecha Wyssogoty Zakrzewskiego i Ludwika de Mathy o wyznaczeniu początku prac nad eksdywizją dóbr Bledzewa na 7 stycznia 1778 r., Poznań, 15 XII 1777, APP, Cystersi Bledzew 125, s. 120-121.

${ }^{76}$ H. Dymnicka-Wołoszyńska, Antoni Ostrowski, PSB, t. 24, Wrocław 1979, s. 544. Andrzej Marek Wyrwa podaje omyłkowo (Lad, w: Monasticon Cisterciense Poloniae, red. A.M. Wyrwa, J. Strzelczyk, K. Kaczmarek, t. 2: Katalog męskich klasztorów cysterskich na ziemiach polskich i dawnej Rzeczypospolitej, Poznań 1999, s. 193-194) nazwisko Andrzeja Kitowicza. W istocie Jędrzej Kitowicz „w styczniu t.r. [1778] wziął w dziewięcioletnią dzierżawę od Ostrowskiego [--] kilka wsi należących do opactwa komendataryjnego lądzkiego", P. Matuszewska, Jędrzej Kitowicz, PSB, t. 12, Wrocław 1967, s. 526.

77 F. Gotartowski do adwokata de Monte, 20 XI 1777, APP, Cystersi Bledzew 138, s. 303. Zob. także APP, Cystersi Ląd 23. 
ojcowskiej miłości Piusa VI, na co król odpowiedział z „właściwym sobie i niezrównanym wdziękiem", deklarując, jak niegdyś, synowski szacunek dla papieża ${ }^{78}$. W pierwszej październikowej depeszy do sekretarza stanu nuncjusz nie szczędził pochwał dla króla oraz jego pełnego rewerencji stosunku do Stolicy Apostolskiej. Zilustrował to, przypominając o niedawnym zamówieniu, złożonym jeszcze na ręce przebywającego w Warszawie Anticiego, które miało być dostarczone znanemu w Rzymie malarzowi, Antonowi Rafaelowi Mengsowi - Stanisław August pragnął obrazu, którego głównym tematem miała być „chwała Piusa VI”79.

Konflikt wokół Bledzewa i Lądu nie był jedynym punktem zapalnym w stosunkach nuncjusza z królem w latach 1777-1778. W początkach 1777 r. oczekiwano od Archettiego skutecznego poparcia królewskiego stanowiska w obliczu planów dworu wiedeńskiego odłączenia od diecezji krakowskiej terytoriów objętych granicami zaboru austriackiego ${ }^{80}$. Jak pisał ks. Władysław Chotkowski, diecezja krakowska „zajmowała tak wielki obszar, że prawie połowę stanowiła całego zaboru, a parafii liczyła więcej, niż wszystkie diecezje galicyjskie obrządku łacińskiego" "W1 .W kwietniu 1774 r. nuncjusz wiedeński, Antonio Eugenio Visconti, po raz pierwszy usłyszał o planach Marii Teresy, by objąć tę część majątku biskupa krakowskiego sekwestrem i uczynić zeń podstawę dochodów nowego biskupa, który dla tych ziem miał być mianowany ${ }^{82}$. Ówczesny biskup krakowski,

78 G.A. Archetti do L.O. Pallaviciniego, 1 X 1777, AV, Segr. Stato, Polonia 332, k. 158v. Archetti dodał komentarz: „Non v'è certamente privato Cavaliere, che sappia essere più fino, ed obbligante di questo sovrano quando vuol esserlo, ed in questa occasione parmi che abbia cercato d'esserlo quanto ha saputo".

79 G.A. Archetti do L.O. Pallaviciniego, 1 X 1777, AV, Segr. Stato, Polonia 332, k. 159r. Jak pisze Ewa Manikowska, „zamówienie nie zostało niestety zrealizowane”. Zob. E. Manikowska, Sztuka i dyplomacja. Kontekst rzymski kolekcjonerstwa Stanisława Augusta, w: Stanisław August i jego Rzeczpospolita. Dramat państwa, odrodzenie narodu, red. A. Sołtys, Z. Zielińska, Warszawa 2013, s. 275.

${ }^{80}$ Stosunek Marii Teresy i Józefa II do spraw kościelnych na terenach I rozbioru zwięźle omówił Richard Butterwick, Polska rewolucja a Kościół katolicki 1788-1792, Kraków 2012, s. 165-167. Zagadnienie to ma w polskiej historiografii bogatą literaturę. Zob. m.in. B. Kumor, Dzieje diecezji krakowskiej do roku 1795, t. 1, Kraków 1998, s. 255-261, a także wcześniejsze badania tegoż autora, ukazujące zagadnienie podziału diecezji krakowskiej jako wstęp do studiów nad dziejami diecezji tarnowskiej: idem, Dzieje polityczno-geograficzne diecezji tarnowskiej, Lublin 1958; idem, Diecezja tarnowska. Dzieje ustroju i organizacji, 1786-1985, Kraków 1985.

${ }^{81}$ W. Chotkowski, Historia polityczna Kościoła w Galicji za rząów Marii Teresy, Kraków 1909, t. 1, s. 308. Szczegóły na temat zawiślańskiej części diecezji zabranej przez Austrię, ibidem, t. 2, s. 12 nn.

${ }^{82}$ Bliski współpracownik kanclerza Wenzela von Kaunitza Friedrich von Binder zasugerował nuncjuszowi, że „powinien Ojciec św. aprobować wszystko, co N. Pani 
Kajetan Sołtyk, nie zamierzał na to przystać. W 1775 r. wyznaczył na swego koadiutora z prawem następstwa brata królewskiego, biskupa płockiego M.J. Poniatowskiego. Dwór wiedeński miał inne plany, a stosowne pisma w tej sprawie zaadresowano do papieża 3 lutego $1777 \mathrm{r}^{83}$

Ponieważ Wiedeń zwrócił się w tej kwestii bezpośrednio do Piusa VI, z pominięciem Stanisława Augusta, ten, dowiedziawszy się o wszystkim od kardynała protektora Rzeczypospolitej, poruszył problem w rozmowie z Archettim 30 marca 1777 r. ${ }^{84}$ Polski król skarżył się na to, iż Maria Teresa nie zwróciła się w sprawie diecezji krakowskiej do niego, pragnął także, by Pius VI nie godził się na żadne ustalenia bez uprzedniego porozumienia monarchów. Prośba króla związana była z faktem, iż o polsko-austriackie porozumienie w sprawie diecezji krakowskiej od dłuższego czasu w Wiedniu starał się bp M.J. Poniatowski. Nuncjusz odpowiedział wymijająco, sugerując królowi skierowanie tych uwag raczej do Garampiego w Wiedniu. Widać też było obawy Archettiego, by nie wywołać zadrażnień z Austrią ${ }^{85}$. Wobec uników rzymskiego dyplomaty Stanisław August wyraził nadzieję, że nie odmówi on przynajmniej przekazania papieżowi królewskiej petycji ${ }^{86}$. Nie złożywszy żadnych obietnic, Archetti ostrzegł sekretarza stanu, iż w grę wchodzi wizerunek Stolicy Apostolskiej w Rzeczypospolitej ${ }^{87}$. W depeszach z jesieni $1777 \mathrm{r}$. nuncjusz zaczął wręcz popierać królewskie starania o ocalenie dochodów z austriackiej części diecezji krakowskiej ${ }^{88}$. Przy okazji pozwolił sobie na uwagę o bezradności Rzeczypospolitej - Stanisław August pragnął, by Rzym osiągnął dlań to, czego nie mogła osiągnąć Polska ${ }^{89}$.

w sprawie diecezji krakowskiej postanowi, bo jedynym jej celem jest dobro dusz, a dla siebie nie chce wziąć ani grosza", ibidem, t. 2, s. 22. Plany takie znane były już w 1773 r. G. Garampiemu, ibidem, s. 37.

83 Ibidem, t. 2, s. 34.

${ }^{84}$ G.A. Archetti do L.O. Pallaviciniego, 2 IV 1777, AV, Segr. Stato, Polonia 332, k. $42 \mathrm{v}-43 \mathrm{r}$.

${ }^{85}$ Ibidem, k. 43r.

${ }^{86}$ „Se il nunzio di Polonia, replicò il Re, ha pur troppo perduto la sua primiera giurisdizione negli stati ceduti alla Casa d"Austria, spero che il Ministro Pontificio presso la mia Persona non mi potrà ricusare di portare a Sua Santità le mie rispettose istanze, allorché io gliene fo premura", ibidem, k. 43r.

87 G.A. Archetti do L.O. Pallaviciniego, 9 IV 1777, AV, Segr. Stato, Polonia 332, k. $46 \mathrm{v}$.

88 „L'affare venendo portato per questo verso ardisco di avanzare le mie calde suppliche, acciocché S. Beatitudine si degni d'incaricare Mons. Nunzio di Vienna di secondare in Pontificio nome la direzione presa da S.M. Polacca", G.A. Archetti do L.O. Pallaviciniego, 12 XI 1777, AV, Segr. Stato, Polonia 332, k. 189r.

${ }^{89}$ "Ciò che la Polonia non può impedire, vorrebbe che Roma lo impedisse", G.A. Archetti do L.O. Pallaviciniego, 1 IV 1778, AV, Segr. Stato, Polonia 332, k. 287r. 
Sprawa podziału diecezji krakowskiej nie została rozwiązana za życia Marii Teresy. Józef II kontynuował pertraktacje z Piusem VI, który jeszcze w 1782 r. podkreślał konieczność porozumienia się z zainteresowanymi rządami, zanim dojdzie do reformy granic diecezji w posiadłościach habsburskich ${ }^{90}$. Podpisanie 4 lipca 1785 r. „przyjacielskiego układu” między rządem austriackim a kapitułą krakowską i administratorem diecezji krakowskiej, bpem M.J. Poniatowskim, regulowało kwestię odszkodowań ${ }^{91}$. Oznaczało to przyjęcie narzuconego przez Józefa II rozwiązania spornej sytuacji $^{92}$ i otworzyło drogę do kanonicznego erygowania na terytorium austriackim diecezji tarnowskiej, z dniem 13 marca 1786 r. (decyzję o jej utworzeniu Józef II podjął już w 1783 r. $)^{93}$.

Wobec ograniczenia aktywności Rzeczypospolitej na arenie międzynarodowej, kontakty Archettiego z polskim monarchą znacznie częściej dotyczyły spraw krajowych. W czerwcu 1778 r. nuncjusz donosił sekretarzowi stanu, iż król intensywnie pracuje nad przygotowaniem nadchodzącego sejmu z nadzieją, że naród będzie tym razem gotów do poparcia jego starań o polepszenie stanu państwa ${ }^{94}$. Poza troską o niedopuszczenie do wyboru posła z grona dysydentów nuncjusz obawiał się głosowania nad projektem Kodeksu praw autorstwa Andrzeja Zamoyskiego ${ }^{95}$. Zamierzał o tym rozmawiać z królem na specjalnej audiencji w Łazienkach 25 czerwca 1778 r. Niespodziewanie jednak Stanisław August źle się poczuł i musiał pożegnać nuncjusza, obiecując spotkanie wkrótce ${ }^{96}$. Doszło do niego w piątek 3 lipca, a w kolejną niedzielę Archetti dodatkowo podjął temat Kodeksu podczas zwykłej audiencji na dworze królewskim ${ }^{97}$. Po wysłuchaniu mocno krytycznych wywodów nuncjusza na temat planów nowej regulacji spraw kościelnych monarcha zapewnił dyplomatę, iż będzie mógł zaprezentować je sejmowi ${ }^{98}$. Rozmów tego

90 D. Beales, Joseph II, t. 2: Against the World, Cambridge $2013\left(2009^{1}\right)$, s. 355.

91 B. Kumor, Dzieje diecezji krakowskiej, s. 256.

${ }_{92}$ R. Butterwick, op. cit., s. 166-167.

93 B. Kumor, Diecezja tarnowska, s. 44-52.

${ }_{94}$ G.A. Archetti do L.O. Pallaviciniego, 17 VI 1778, AV, Segr. Stato, Polonia 333, k. 22v.

95 Zagadnienie Kodeksu było podejmowane w polskiej historiografii kilkakrotnie, zob. M. Tarnawski, Kodeks Zamoyskiego na tle stosunków kościelno-państwowych za czasów Stanisława Augusta, Lwów 1916; Ł. Kurdybacha, op. cit. (pracę opatrzyli krytycznymi recenzjami: Jerzy Michalski, PH 42, 1951, s. 444-452, oraz Bogusław Leśnodorski, CPH 4, 1952, s. 466-480); E. Borkowska-Bagieńska, Zbiór praw sądowych Andrzeja Zamoyskiego, Poznań 1986. W kontekście obrad sejmu 1778 r. o kwestii tej pisał także Witold Filipczak, Sejm 1778 r., Warszawa 2000.

96 G.A. Archetti do L.O. Pallaviciniego, 1 VII 1778, AV, Segr. Stato, Polonia 333, k. 36r.

97 G.A. Archetti do L.O. Pallaviciniego, 8 VII 1778, AV, Segr. Stato, Polonia 333, k. 38r.

98 Ibidem, k. 40r. Pisząc o sejmie 1778 r., W. Filipczak wspomniał o antykodeksowych 
rodzaju odbyło się w kolejnych miesiącach wiele. Archetti wyniósł z nich przekonanie, iż król miał dobrą wolę, ale w sprawach kościelnych zbytnio ulegał nowoczesnym trendom („discorsi e pensamenti del secolo”) ${ }^{99}$. Choć w przypadku Stanisława Augusta - jak się wydaje - bardziej było to związane z ogólną atmosferą oświeceniowego reformizmu niż z systematycznym wdrażaniem innowacji o charakterze józefińskim, nuncjusz przy kolejnej okazji wyraził zaniepokojenie faktem, że król, mimo dobrej woli, zbyt często ulega ludziom o złych intencjach ${ }^{100}$.

Pozostawiając szerszą analizę stosunku Archettiego do Kodeksu Zamoyskiego podczas sejmu 1778 r. do osobnego opracowania, warto tu zaznaczyć, iż negatywne nastawienie nuncjusza do projektu praw, na którym bardzo królowi zależało, nie zaowocowało konfliktem ani nawet ochłodzeniem wzajemnych stosunków. Gdy sejm 1780 r. ostatecznie odrzucił projekt Kodeksu, nuncjusz zachował się dyplomatycznie, nie okazując nadmiernego zadowolenia. W depeszy do kard. Pallaviciniego raz jeszcze podkreślił intencję Stanisława Augusta, by w niczym nie naruszyć praw kurii rzymskiej. Zdaniem nuncjusza polski monarcha zasługiwał na szczególną wdzięczność papieża za swą lojalność wobec Kościoła ${ }^{101}$.

5 listopada 1780 r. nuncjusz wydał obiad dla 20 polskich biskupów obecnych na sejmie. Nagłym pojawieniem się zaskoczył go Stanisław August, publicznie obsypując Archettiego komplementami i wyrazami szacunku ${ }^{102}$. Nuncjusz chętnie cytował świadczące o owym szacunku wypowiedzi króla: „Cieszę się, że przy tej, jak i każdej innej okazji dostrzega się, iż jestem synem najbardziej posłusznym i przywiązanym do Stolicy Apostolskiej oraz pełnym uczucia dla wspaniałego i niezrównanego papieża Piusa VI"103. Nuncjusz dementował też w depeszach

działaniach Archettiego, dodał jednak: „Znacznie groźniejsza dla projektu miała się okazać niechęć O. Stackelberga”, W. Filipczak, op. cit., s. 148; oraz: „Na stanowisko Stanisława Augusta wpływ miała postawa Stackelberga, a w mniejszym stopniu antykodeksowe działania nuncjusza G.A. Archettiego" (s. 183).

99 G.A. Archetti do L.O. Pallaviciniego, 26 VIII 1778, AV, Segr. Stato, Polonia 333, k. 61r.

100 „Non dubiterei della sincerità de' suoi sentimenti, se non mi restasse qualche timore sul di lui animo, che non di rado si lascia piegare anche da chi cerca d'inclinarlo dalla parte non buona", G.A. Archetti do L.O. Pallaviciniego, 16 IX 1778, AV, Segr. Stato, Polonia 333, k. 69r.

101 G.A. Archetti do L.O. Pallaviciniego, 4 XI 1780, AV, Segr. Stato, Polonia 335, k. 143r.

102 G.A. Archetti do L.O. Pallaviciniego, 8 XI 1780, AV, Segr. Stato, Polonia 335, k. 149v.

103 „Godo, che tanto in questa occasione, quanto in ogni altra si scorga, che io sono il figlio il più attaccato, ed obbediente alla $\mathrm{S}$. Sede Apostolica, ed il più affettuoso verso l'ottimo, ed incomparabile Sommo Pontefice Pio VI", G.A. Archetti do L.O. Pallaviciniego, 26 I 1780, AV, Segr. Stato, Polonia 334, k. 140v. Relacja ta wiązała się z krótkotrwałym zaangażowaniem króla w negocjacje między papieżem i Katarzyną II w sprawie 
plotki, jakie publikowano na temat Stanisława Augusta w europejskich gazetach - np. o jego bliskiej śmierci czy abdykacji, albo nowych konfederacjach w Rzeczypospolitej. Papieski wysłannik podkreślał brak podstaw tych pogłosek, a równocześnie zastanawiał się, „z jakiego mrocznego miejsca te kłamstwa się wywodzą"104.

Archetti nie krył swej sympatii dla króla, ze współczuciem patrzył na upokorzenia, jakich doświadczał on ze strony zaborców. Szczególny wyraz tym spostrzeżeniom dał w serii depesz z końca 1781 r. w związku z podróżą króla na spotkanie z rosyjską parą wielkoksiążęcą, Pawłem i Marią Fiodorowną, w Wiśniowcu. Dla nuncjusza był to wyraz nadmiernej uległości Stanisława Augusta, kolejna okazja do triumfu rosyjskiej pychy (,progetto che tutto torna in trionfo della superbia Russa”) ${ }^{105}$. Stackelberg odprowadził króla do Kozienic, aby następnie na żądanie Katarzyny II wrócić do Warszawy ${ }^{106}$. Zdaniem Archettiego to raczej wielki książę Paweł powinien był przybyć do stolicy Rzeczypospolitej na spotkanie króla, a gdyby to nie wchodziło w grę, to witać przy granicy królestwa powinien go rosyjski ambasador, a nie monarcha. Tymczasem ambasador pozostawał w Warszawie, a w kilkusetkilometrową podróż wyruszał Stanisław August ${ }^{107}$.

31 października rosyjska para książęca, podróżująca incognito jako „hrabstwo du Nord”, dotarła do Wiśniowca. 1 listopada doszło do spotkania ze Stanisławem Augustem, z gospodarzami (marszałek Michał Mniszech

jezuitów w Rosji. Na przełomie lutego i marca 1780 r. stało się jasne, że caryca nie życzyła sobie dalszego udziału Stanisława Augusta w tej sprawie. Zob. M. Loret, Kościót katolicki a Katarzyna II, s. 157, 280-281.

104 G.A. Archetti do L.O. Pallaviciniego, 5 I 1780, AV, Segr. Stato, Polonia 334, k. 125 r.

105 G.A. Archetti do L.O. Pallaviciniego, 19 IX 1781, AV, Segr. Stato, Polonia 335, k. 274v. Szerzej genezę podróży króla do Wiśniowca oraz znaczenie inicjatywy strony polskiej w realizacji tego projektu naświetla korespondencja Stanisława Augusta z polskim posłem w Petersburgu, Augustynem Debolim, począwszy od lipca $1781 \mathrm{r}$., zob. AGAD, Archiwum Królestwa Polskiego (dalej: AKP) 262, k. 557v nn. oraz AKP 263, k. 308 nn. Dziękuję Ewie Zielińskiej za udostępnienie transkrypcji tej korespondencji. Zob. także list Stanisława Augusta do Katarzyny II, Warszawa, 12 VIII 1781, AKP 226, k. 332, oraz odpowiedź Katarzyny II, Carskie Sioło, 12 VIII 1781, AKP 226, k. 333-333v, transkrypcja wraz z komentarzem Zofii Zielińskiej, [nr 160], Correspondance de Stanislas-Auguste avec Catherine II et ses plus proches collaborateurs (1764-1796), oprac. Z. Zielińska, Kraków 2015, s. 395-398. Dziękuję Zofii Zielińskiej za udostępnienie wstępnej redakcji przygotowywanej publikacji.

106 Podróż rozpoczęła się 9 X 1781, zob. G.A. Archetti do L.O. Pallaviciniego, 10 X 1781, AV, Segr. Stato, Polonia 335, k. 277r. Zob. „Gazeta Warszawska” 1781, nr 81 (10 października) oraz kolejne numery.

107 G.A. Archetti do L.O. Pallaviciniego, 15 X 1781, AV, Segr. Stato, Polonia 335, k. $278 \mathrm{v}-279 \mathrm{r}$. 
żonaty z królewską siostrzenicą, Urszulą z Zamoyskich) i z przedstawicielami kilku rodzin magnackich. Uroczystości trwały kilka dni, 5 listopada nastąpiło „serdeczne aż do rozrzewnienia z obojej strony publiczne pożegnanie" króla i książęcej pary, która wyruszała w dalszą podróż, odprowadzana kilka mil przez Stanisława Augusta ${ }^{108}$. Ten zaś podążył jeszcze do Kamieńca Podolskiego, obejrzał fortecę, następnie skierował się z powrotem w stronę Warszawy ${ }^{109}$.

Podróż, mająca być kolejnym znakiem upokorzenia króla wobec Rosji, obróciła się na korzyść monarchy. Nuncjusz z zadowoleniem donosił o zdumieniu wielkiego księcia Pawła oznakami przywiązania szlachty do Stanisława Augusta - wbrew opinii o niezwykle słabej pozycji króla w narodzie ${ }^{110}$. Archetti zdawał się sugerować, że na podtrzymywaniu takiej opinii na dworze petersburskim zależało szczególnie Stackelbergowi. Aby przyćmić pozytywne wrażenia związane z podróżą króla do Wiśniowca, rosyjski ambasador miał ze szczególną powagą potraktować absurdalną pogłoskę o rzekomej próbie zamachu na życie króla podczas triumfalnego wjazdu monarchy do Warszawy, 8 grudnia $1781 \mathrm{r}^{111}$ Śledztwo zaprzeczyło takim spekulacjom, a nuncjusz uznał je albo za owoc chorego umysłu, albo za celowe machinacje Stackelberga. Ambasadorowi, jak sądził Archetti, zależało na utrwaleniu obrazu króla jako władcy słabego i pozbawionego szacunku swego narodu, czemu w sposób spektakularny zaprzeczała wiśniowiecka podróż ${ }^{112}$.

108 „Gazeta Warszawska” 1781, nr 89 (7 listopada), 90 (10 listopada), 91 (14 listopada). Cytat z numeru 91, s. 2.

109 „Gazeta Warszawska” 1781, nr 94 (24 listopada) i 95 (28 listopada) opisuje wizytę króla w fortecy kamienieckiej.

110 G.A. Archetti do L.O. Pallaviciniego, 5 XI 1781, AV, Segr. Stato, Polonia 335, k. 283r. „Gazeta Warszawska” donosiła: „Król JMć Po wszystkich prawie wsiach i miasteczkach, którędy przejeżdża, od zgromadzonych umyślnie obywatelów pobliższych, tudzież mieszczan i włościan wychodzących na gościniec i czekających na przyjęcie i powitanie JKM odbiera dowody przywiązania Narodu do Monarchy swego". Zob. „Gazeta Warszawska” 1781, nr 83 (17 października), s. 1.

${ }^{111}$ Interesujący opis wjazdu króla, zob. „Gazeta Warszawska” 1781, nr 99 (12 grudnia). Brak w nim wzmianki o rzekomym zamachu.

112 „Bisognerebbe poi esser privo di buon senso, e di ragione per credere, che siesi potuto scegliere quel tempo, e quel luogo ad eseguire si orribile disegno. [--]. L'Ambasciator di Russia è quello, che ha dato maggior corpo a quest'ombra. [--] L'amore mostrato ora verso del Re da suoi sudditi auria potuto smentire, e distruggere la contraria opinione, che si è sempre cercato d'imprimere altamente nell'animo dell'Imperatrice. Dunque o è stato inventato di pianta, o si vuol cavar profitto dall'accidente descritto per confermare quella stessa opinione", G.A. Archetti do L.O. Pallaviciniego, 19 XII 1781, AV, Segr. Stato, Polonia 335, k. 299r-v (opis całej sytuacji 298v-299v). Por. J. Michalski, Zmierzch prokonsulatu Stackelberga, w: Studia historyczne z XVIII i XIX wieku, t. 1, s. 449-499. 
W ostatnim roku pobytu papieskiego dyplomaty w Warszawie dwie sprawy znów doprowadziły do chwilowej konfrontacji z królem, choć natężenie emocji nie było już tak wysokie, jak w kwestii opactw.

Z końcem $1781 \mathrm{r}$. wikariusz generalny biskupa wileńskiego Ignacego Massalskiego, Piotr Toczyłowski, zwrócił się do Archettiego z prośbą o dyspensę potrzebną do święceń kapłańskich dwukrotnie żonatego, siedemdziesięcioletniego Benedykta Oganowskiego ${ }^{113}$. Archetti udzielił jej warunkowo, domagając się wyjaśnienia pogłosek o oskarżeniach, jakich przedmiotem miał być ów litewski szlachcic. Z dyspensy skorzystano natychmiast, nie zważając na te zastrzeżenia, zatem do święceń doszło. Już po fakcie wyszło na jaw, iż na Oganowskim ciążyło oskarżenie o rozbój. Zaczęto podejrzewać, że święcenia kapłańskie były wybiegiem, by uniknąć sprawiedliwości dzięki immunitetowi chroniącemu duchownych. Nuncjusz był oburzony na bpa Massalskiego i jego wikariusza, czuł się wprowadzony w błąd ${ }^{114}$. Równie oburzeni sędziowie Trybunału Litewskiego, kierowanego przez księcia Adama Kazimierza Czartoryskiego, nie zamierzali respektować prawa Oganowskiego do rozprawy przed sądem kościelnym. Winowajca został szybko schwytany, Stanisław August popierał jego proces przed Trybunałem Litewskim. Archetti podjął jednak w rozmowach z królem problem precedensu, grożącego naruszeniem struktury prawa kościelnego w Rzeczypospolitej. Zdaniem nuncjusza Oganowski powinien zostać osądzony przez trybunał kościelny ${ }^{115}$. Tego domagał się także biskup wileński, grożąc karami kościelnymi wszystkim, którzy by naruszyli ów przywilej. Ostatecznie wyznaczono kościelne instancje do rozsądzenia sprawy. Winny został skazany na dożywotni pobyt $\mathrm{w}$ wyznaczonym klasztorze ${ }^{116}$.

Niemalże w tym samym czasie rozgorzał spór wokół stanu zdrowia bpa Sołtyka i jego zaskakujących decyzji, m.in. interdyktu rzuconego na kapitułę krakowską ${ }^{117}$, a następnie planów podróży do Galicji, którym

113 Por. L. Wolff, op. cit., s. 142, 144-146, 148-151.

114 G.A. Archetti do L.O. Pallaviciniego, 13 II 1782, AV, Segr. Stato, Polonia 336, k. $17 \mathrm{v}-19 \mathrm{v}$.

115 Szersza dokumentacja sprawy Oganowskiego, zgromadzona przez nuncjusza, zob. [Diocesi di] Vilna. Lettere risguardanti l'affare di Ogonowski, commissione, relazione e processo, AV, Nunz. Varsavia 145, k. 523r-609r.

116 Listy bpa Massalskiego w tej sprawie znajdują się w Bibliotece Uniwersytetu Wileńskiego, Kapituła Wileńska, F57, Б53-1388, k. 16v-24r, 27v-31r. Rozbieżne relacje: A.J. Czartoryski, Pamiętniki i memoriały polityczne 1776-1809, Warszawa 1986, s. 86-87; J.U. Niemcewicz, Pamiętniki czasów moich, Lipsk 1868, s. 56 oraz wydanie późniejsze tychże, Warszawa 1957, t. 1, s. 154 (wraz z przypisem). Zob. także E. Raila, Ignotus Ignotas. Vilniaus vyskupas Ignotas Jokūbas Masalskis, Vilnius 2010, s. 72-73.

117 G.A. Archetti do L.O. Pallaviciniego, 16 II 1782, AV, Segr. Stato, Polonia 336, k. 22v-23r. 
przeszkodzili kanonicy, zatrzymując biskupa siłą w Krakowie ${ }^{118}$. Kwestia ma sporą historiografię, toteż tutaj skupimy się jedynie na tych jej aspektach, które dotyczą roli w niej Archettiego i związanych z tym jego relacji z królem ${ }^{119}$. Ze względu na to, że sprawa stała się przedmiotem ostrego sporu politycznego, król zdecydował o powołaniu komisji do zbadania zasadności doniesień o chorobie umysłowej hierarchy ${ }^{120}$. Wywołało to reakcję Archettiego, który przypomniał, że zgodnie z zasadą prymatu jurysdykcji kościelnej powoływanie jakichkolwiek komisji dla zbadania stanu zdrowia duchownego oraz oceny, czy fakt ten zmusza do wyznaczenia administratora diecezji, leżało w gestii nuncjusza i Stolicy Apostolskiej. Król nie oponował, ale podnosił, że Sołtyk był nie tylko duchownym, lecz także senatorem Rzeczypospolitej, posiadającym dobra niewchodzące w zakres jurysdykcji kościelnej. Sprawa wymagała nadto rozstrzygnięć szybkich, uniemożliwiających oczekiwanie na decyzję Rzymu ${ }^{121}$.

Stanisław August odrzucił „kompromisową" sugestię Archettiego, by komisja składała się wyłącznie z duchownych wyznaczonych do tej funkcji zarówno przez nuncjusza, jak i przez króla, za despekt uznał też nuncjusz powierzenie nadzoru nad poprawnością całej procedury od strony kościelnej prymasowi. Ponieważ jednak bp Antoni Okęcki zgodził się z argumentacją o szczególnej kompetencji Stolicy Apostolskiej w sprawie Sołtyka jako biskupa, nuncjusz przystąpił do samodzielnego tworzenia komisji. Działał wyłącznie dla podkreślenia własnej pozycji jako reprezentanta papieża i ostatecznie powołał do niej obu duchownych, którzy mieli być już powołani przez króla do pierwotnej komisji, a więc biskupa poznańskiego Okęckiego oraz biskupa chełmskiego Macieja Garnysza ${ }^{122}$.

118 G.A. Archetti do L.O. Pallaviciniego, 27 II 1782, AV, Segr. Stato, Polonia 336, k. 41r.

119 Zob. K. Rudnicki, Biskup Kajetan Sołtyk 1715-1788, Kraków 1906, s. 215. Sprawę bpa Sołtyka niedawno omówił także R. Butterwick, op. cit., s. 218-222. Zob. także M. Czeppe, Kajetan Ignacy Sołtyk, PSB t. 40, Warszawa-Kraków 2001, s. 386-404; E. Zielińska, „Rzeczpospolita wobec zbliżenia rosyjsko-austriackiego na początku lat osiemdziesiątych XVIII w. Sprawy Barona Karla Juliusa i Biskupa Kajetana Sołtyka", Warszawa 2004, mps pracy doktorskiej, Instytut Historii PAN; S. Zawadzki, „Zwaryowany na umyśle biskup" czy ofiara intrygi? Sprawa biskupa krakowskiego Kajetana Soltyka w 1782 r. w świetle gazetek pisanych Teodora Ostrowskiego, Warszawa 2013, mps pracy licencjackiej napisanej pod kierunkiem Piotra Ugniewskiego, Uniwersytet Warszawski, Wydział Historyczny.

${ }^{120}$ Na temat dyskusji toczonych przez Radę Nieustającą zob. K. Rudnicki, op. cit., s. $217 \mathrm{nn}$.

121 G.A. Archetti do L.O. Pallaviciniego, 6 III 1782, AV, Segr. Stato, Polonia 336, k. $44 \mathrm{r}-\mathrm{v}$.

122 Ibidem, k. 44v-45v oraz G.A. Archetti do L.O. Pallaviciniego, 9 III 1782, AV, Segr. Stato, Polonia 336, k. 51r. Skład pierwszej, „królewskiej” komisji zob. K. Rudnicki, op. cit., s. 220. Powyższa konstatacja wynika z lektury depesz nuncjusza porównanych 
Dalsze dysputy z królem Archetti odbył po powołaniu kuratorów do opieki nad Sołtykiem i jego majątkiem. I tym razem nie zdołał przekonać króla do poddania całej procedury aprobacie papieskiej, choć Stanisław August obiecał nuncjuszowi, iż w królewskim przywileju nie będzie mowy o nadzorze kuratorów nad majątkiem diecezji, a jedynie nad osobą chorego biskupa oraz jego własnymi dobrami materialnymi ${ }^{123}$. Archetti referował przebieg sprawy Sołtyka zarówno sekretarzowi stanu, jak i Garampiemu w Wiedniu, gdzie od 22 lutego do 22 marca przebywał Pius VI jako gość Józefa II. Otrzymawszy papieskie pełnomocnictwa, 6 maja 1782 r. ogłosił zarządcą diecezji dotychczasowego koadiutora, bpa Poniatowskiego; było to ustępstwem wobec Stanisława Augusta, zgrabnie ujętym w dyplomatyczne ramy ${ }^{124}$.

Gestem życzliwości Stanisława Augusta wobec Archettiego po zakończeniu trudnej sprawy było zaproszenie nuncjusza na dłuższy pobyt $\mathrm{w}$ Łazienkach, latem $1782 \mathrm{r}^{125} \mathrm{~W}$ depeszach $\mathrm{z}$ tego okresu znów pojawiają się zwroty o „doskonałym królu” („questo ottimo sovrano”), „jednym z najbardziej oddanych i życzliwych [Piusowi VI] władców”126. Archetti towarzyszył królowi niemal do końca lata, także podczas odwiedzin w Jabłonnie, 7 września, poprzedzających powrót do stolicy ${ }^{127}$. Komentując zmarnowanie przez opozycję sejmu 1782 r., nuncjusz, pełen współczucia dla króla, stwierdzał, że Rosja nie musi ingerować w polskie sprawy, gdyż Polacy, idąc za swą „naturalną skłonnością”, sami podsycają wzajemne konflikty i przeciwstawiają się dworowi. Mógł nie zdawać sobie sprawy, że za owym podsycaniem konfliktów niejednokrotnie stała

z opracowaniem Kazimierza Rudnickiego. Po dokładnym przeanalizowaniu kwestii składu komisji królewskiej Stanisław Zawadzki stwierdził, że bp Garnysz do niej nie należał. Zob. artykuł S. Zawadzkiego, Polityczne spory wokół aresztowania biskupa krakowskiego Kajetana Soltyka w 1782 r. w świetle gazetek pisanych Teodora Ostrowskiego, przyjęty do druku w „Przeglądzie Historycznym” (2016, nr 2). Za jego udostępnienie dziękuję autorowi. Wg cytowanego przezeń diariusza sejmu 1782 r. „w składzie komisji znaleźli się: Antoni Okęcki, Bazyli Walicki, Piotr Ożarowski, Tomasz Ostrowski, Franciszek Szymanowski oraz Michał Walewski".

123 G.A. Archetti do L.O. Pallaviciniego, 10 IV 1782, AV, Segr. Stato, Polonia 336, k. 64r, 69r.

124 G.A. Archetti do L.O. Pallaviciniego, 8 V 1782, AV, Segr. Stato, Polonia 336, k. $78 \mathrm{v}-79 \mathrm{r}$.

125 „La Maestà Sua mi ha fatto l'onore d'invitarmi a tenerle compagna, e mi ha destinato un appartamento in detta sua villa", G.A. Archetti do L.O. Pallaviciniego, 3 VII 1782, AV, Segr. Stato, Polonia 336, k. 91v.

126 G.A. Archetti do L.O. Pallaviciniego, 17 VII, 21 VIII 1782, AV, Segr. Stato, Polonia 336, k. 96v, 105r.

127 G.A. Archetti do L.O. Pallaviciniego, 4 IX 1782, AV, Segr. Stato, Polonia 336, k. $107 \mathrm{v}$. 
właśnie Rosja. Znamienna była opinia o Stanisławie Auguście, wyrażona jesienią 1782 r., pod świeżym wrażeniem zmarnowanego sejmu:

Krzywdzi się króla, przypisując mu plany i zamierzenia absolutystyczne. On jest pierwszym republikaninem z natury i dzięki wykształceniu, jakie otrzymał w szkole zmarłych książąt Czartoryskich. Słusznie jednak uważa się, iż posiada wiedzę większą niż którykolwiek z jego poddanych, albo lepiej powiedziawszy, współobywateli, i pragnie uszczęśliwić swój naród do tego stopnia, że aż łudzi się co do tego, na ile pozwoli mu polityka potężniejszych sąsiadów, zgodnie z aktualnym stanem rzeczy ${ }^{128}$.

Król pragnie - kontynuował nuncjusz - by naród był przekonany o jego talentach i gorliwości, by wierzył, że motywem jego działań jest dobro społeczeństwa i państwa ${ }^{129}$. Dlatego często poświęca sporo energii na zbliżenie się do przeciwników, dając im dowody życzliwości. Tak było i na zakończonym właśnie sejmie, gdy król, mając dużą przewagę nad opozycją, przyczynił się, zdaniem Archettiego, do niepotrzebnej straty czasu, chcąc na próżno zadowolić kilku zaciekłych przeciwników ${ }^{130}$.

Duże znaczenie, jakie król przypisywał obecności nuncjusza na swoim dworze, widać po jego reakcji na wieść o tym, że Archetti, wyznaczony wiosną 1783 r. do pełnienia misji papieskiego legata w Petersburgu, zostanie tymczasowo zastąpiony przez internuncjusza ${ }^{131}$. Oznaczało to obniżenie rangi papieskiego reprezentanta w Rzeczypospolitej, jak liczył Stanisław August, tylko chwilowe ${ }^{132}$. Jednocześnie monarcha popierał kandydaturę Archettiego do misji na dworze Katarzyny II $^{133}$, a nuncjusz, uzyskawszy akceptację imperatorowej, przypisywał swe wyróżnienie „szczególnej życzliwości” króla oraz „przyjaźni” Stackelberga ${ }^{134}$.

128 „Si fa gran torto al Re attribuendogli dei disegni, e delle mire per divenir sovrano più assoluto. Egli è il primo republicano per indole, e per educazione avuta alla scuola dei defonti principi Czartoryski. Ma con ragione si crede fornito di maggiori cognizioni, che qualunque suo suddito, o vogliam dire concittadino, e desidera render felice la sua Nazione sino a fare illusione a se medesimo sopra di ciò, che la politica dei vicini più potenti non sarà mai per permettergli durante lo stato attuale delle cose", G.A. Archetti do L.O. Pallaviciniego, 20 XI 1782, AV, Segr. Stato, Polonia 336, k. 185r.

129 Ibidem, k. $185 \mathrm{v}$.

130 Ibidem.

131 Przyczyny, które skłoniły papieża do wysłania przedstawiciela na dwór Katarzyny II, omówił M. Loret, Kościół katolicki a Katarzyna II, s. 174-196. Samą misję opisał i źródła do niej wydał Marie-Joseph Rouët de Journel, op. cit.

132 G.A. Archetti do L.O. Pallaviciniego, 3 V 1783, AV, Segr. Stato, Polonia 336, k. $247 \mathrm{v}-248 \mathrm{r}$.

133 G.A. Archetti do L.O. Pallaviciniego, 5 III 1783, AV, Segr. Stato, Polonia 336, k. 224v.

134 G.A. Archetti do L.O. Pallaviciniego, 23 III 1782, AV, Segr. Stato, Polonia 336, k. 228v. 
Natychmiast po otrzymaniu wieści o nowym przeznaczeniu Archettiego Stanisław August wyraził przekonanie, że będzie to oznaczało także nominację kardynalską, co podkreśli rangę nuncjatury warszawskiej ${ }^{135}$. 11 czerwca 1783 r. Archetti żegnał się w Łazienkach ze Stanisławem Augustem $^{136}$. Do ponownego spotkania miało dojść rok później, w Grodnie, gdzie powracający z Rosji Archetti oczekiwał na ceremonię wręczenia biretu kardynalskiego z rąk polskiego króla. Ten zaś przewodniczył ceremonii z widoczną satysfakcją, choć nie było już wówczas mowy o znaczeniu nuncjatury warszawskiej, ale jedynie o randze misji spełnionej przez Archettiego w Petersburgu ${ }^{137}$.

Uzupełniając przegląd relacji Archettiego ze Stanisławem Augustem, dodać należy, iż poza tematyką oficjalną nuncjusz był także obserwatorem codziennych poczynań króla i o niektórych informował sekretarza stanu. Pozwalał sobie nieraz na bardzo bezceremonialne zachowania, jak np. konfiskatę książki Salvatore Venturiego Delle monache $e^{138}$, której pięknie oprawiony egzemplarz autor przesłał królowi. Ponieważ dzieło miało jawny wydźwięk antykościelny, Archetti nie zamierzał go królowi oddawać ${ }^{139}$. Wielokrotnie informował o tym, iż Stanisław August celowo wyjeżdżał z Warszawy w dniu swych imienin albo w rocznice elekcji i koronacji, aby uniknąć dworskich ceremonii. Z kolei w dniu imienin nuncjusza król nie zapominał o podarku dla dyplomaty ${ }^{140}$. Do całkiem prywatnych inicjatyw Archettiego, przyjętych życzliwie przez Stanisława Augusta, należała prośba o dekorację Orderem św. Stanisława siostrzeńca nuncjusza, Giovanniego-Battisty Vertovy z Begamo ${ }^{141}$. W 1791 r. ten

135 Kluczowe zdanie brzmi: „Non dubitiamo parimenti, che in vigore del Sistema già inveterato riguardo al Nunzio Apostolico, il quale partendo dalla Nostra Corte, o non deve passare all'altra, che all'Imperial di Vienna, [v] o deve essere rivestito di altra Carica Cardinalizia, riguarderassi questa straordinaria Ambasciata a Pietroburgo del Rmo Archetti come se all'uno o all'altro grado fosse stato promosso, sicché da essa Ambasciata verrà direttamente dichiarato Cardinale", Stanisław August Poniatowski do T. Anticiego, 26 III 1783, Archivio Antici Mattei, Recanati, Busta 15, Fascicolo 5, nr 40.

136 G.A. Archetti do L.O. Pallaviciniego, 13 VI 1783, AV, Segr. Stato, Polonia 338, k. 7r.

137 Genezę tego wydarzenia i samą ceremonię omawiam szczegółowo w artykule „Jeden z najszczęśliwszych dni króla Stanisława Augusta”, s. 311 nn.

138 S. Venturi, Delle Monache, Lucca 1776.

139 G.A. Archetti do L.O. Pallaviciniego, 16 IV 1777, AV, Segr. Stato, Polonia 332, k. 49r.

140 G.A. Archetti do L.O. Pallaviciniego, 25 VI 1777, AV, Segr. Stato, Polonia 332, k. $94 \mathrm{v}$.

141 Zob. pokwitowanie wpłaty 28 dukatów za pierwszy rok po dekoracji, AGAD, Archiwum Ghigiottiego 961, k. 94r. Vertova otrzymał order w 1779 r. Zob. Z. Dunin-Wilczyński, Order św. Stanisława, Warszawa 2006, s. 186. Nazwisko w spisie dekorowanych zapisano błędnie: Vertorova. 
ostatni powtórnie zwrócił się do polskiego króla z prośbą, tym razem o dekorację Orderem Orła Białego. Uzyskał ją natychmiast, a w towarzyszącym wyróżnieniu liście król zamieścił kilka kurtuazyjnych słów o Archettim ${ }^{142}$. Te przykłady świadczą o elementach relacji nuncjusza z królem nieudokumentowanych w oficjalnych depeszach do sekretariatu stanu.

W historiografii Archetti uchodzi za osobę ambitną, lecz przeciętną ${ }^{143}$. Bywał przeciwstawiany swemu poprzednikowi w Warszawie, Garampiemu ${ }^{144}$. Skłania to do ostrożności w ocenie zarówno działań, jak sądów ferowanych przez Archettiego. Pochlebna opinia o królu, wyrażana przez osobę „przeciętną i ambitną”, niekoniecznie służy budowaniu pozytywnego obrazu człowieka przezeń chwalonego. Wypada jednak stwierdzić, że w depeszach Archetti przekazywał sekretarzowi stanu pozytywny obraz Stanisława Augusta. Podkreślał jego szacunek dla Piusa VI, zatroskanie o dobro kraju, łagodność charakteru i doskonałe maniery. Polityczna zależność króla od rosyjskiego ambasadora nie stanowiła zarzutu wobec monarchy, przeciwnie, nuncjusz wydawał się współczuć polskiemu władcy z powodu okoliczności, w jakich przyszło mu kierować państwem. Z tego punktu widzenia opinie Archettiego z lat 1776-1784 odbiegają od bardziej krytycznych zapatrywań na króla jego poprzedników, jak Visconti czy Durini. Otwarte pozostaje pytanie - w jakim stopniu owa zmiana w postrzeganiu króla była związana $\mathrm{z}$ indywidualną wrażliwością papieskich dyplomatów, w jakim zaś mogła wynikać z ewolucji postawy samego Stanisława Augusta oraz pogarszającej się sytuacji Rzeczypospolitej.

142 G.B. Vertova do Stanisława Augusta Poniatowskiego, 20 VIII 1791 i 3 XII 1791, AGAD, Arch. Ghigiottiego 901, k. 1-1v, 3-3v. Król pisał w odpowiedzi: „Molto più per altro merita la nostra considerazione quando ne viene da un Cavalier distinto per nascita e per le qualità personali, e che gode come lei la fortunata prerogativa di essere cosi strettamente congiunta di sangue con il Nostro Amico il signor cardinal Archetti, del quale abbiamo Noi goduta per più anni alla Nostra Corte l'amabile compagnia", Stanisław August Poniatowski do G.B. Vertovy, 12 XI 1791, AGAD, Arch. Ghigiottiego 901, k. 5-5v. W spisie kawalerów orderu pokrewieństwo Giovanniego Battisty Vertovy z Archettim nie zostało uwzględnione. Zob. Kawalerowie i statuty Orderu Orła Białego, 1705-2008, red. M. Męclewska, Warszawa 2008, s. 258 (nr 921).

143 Zob. P. Zając, Polska i Polacy, s. 416-420.

144 Un Nonce du Pape à la cour de Catherine II. Memoires d'Archetti, red. J. Gagarin SJ, Paris-Bruxelles 1872, s. X-XII. 


\section{Streszczenie}

W artykule omówione zostały wzajemne stosunki króla Stanisława Augusta Poniatowskiego oraz Giovanniego Andrei Archettiego, nuncjusza papieskiego w Rzeczypospolitej w latach 1776-1784. Informacje na temat polskiego króla były ważną częścią depesz przesyłanych przez nuncjusza do rzymskiego sekretariatu stanu. Królowi zależało na pozytywnym wizerunku. Kilka potencjalnie kryzysowych sytuacji na płaszczyźnie państwo-Kościół rozwiązano w tym okresie ugodowo. W korespondencji Archettiego mowa jest często o królewskich deklaracjach wierności Stolicy Apostolskiej i przywiązaniu monarchy do papieża Piusa VI. Stanisław August milcząco przyzwolił na zakulisową akcję nuncjusza przeciw wyborowi posła-dysydenta na sejmiku we Wschowie w 1776 r., nie zgadzał się także na projekty dodatkowych podatków na instytucje kościelne w dobrach królewskich. Jednocześnie dość stanowczo nalegał na przejęcie kontroli nad dobrami opackimi klasztorów cysterskich w Lądzie i Bledzewie i nie spełnił wszystkich żądań Archettiego co do procedury objęcia kuratelą biskupa krakowskiego Kajetana Sołtyka. Bardziej pojednawczo zachował się przy okazji procesu Benedykta Oganowskiego, który z racji przyjętych święceń podlegał jurysdykcji kościelnej, choć miał być sądzony za wcześniejsze przestępstwa, popełnione jeszcze w stanie świeckim. Upadek projektu Kodeksu praw Andrzeja Zamoyskiego, mimo zaangażowania w tę sprawę nuncjusza, nie wpłynął na zmianę tonu, w jakim król deklarował pełną lojalność wobec Piusa VI i manifestował życzliwość wobec papieskiego dyplomaty. Archetti pisał o królu z sympatią, a nawet współczuciem, widząc jego starania o reformę Rzeczypospolitej i jednoczesną polityczną niemoc, podtrzymywaną zwłaszcza przez Rosję. W tym tonie relacjonował podróż króla do Wiśniowca w 1781 r. na spotkanie z parą wielkoksiążęcą, Pawłem i Marią Fiodorowną. Pozytywne osobiste kontakty z nuncjuszem Stanisław August potwierdził, dekorując Orderem św. Stanisława i Orderem Orła Białego siostrzeńca Archettiego, Giovanniego Battistę Vertovę, którego jedynym atutem było pokrewieństwo z Giovannim Andreą.

\section{Giovanni Andrea Archetti and Stanisław August Poniatowski. A Portrayal of the King and Mutual Relations in Dispatches from the Nuncio to the Secretariat of State at the Apostolic See in 1776-1784}

The article studies mutual relations between King Stanisław August Poniatowski and Giovanni Andrea Archetti, the papal nuncio in the Commonwealth from 1776 to 1784 . Information about the Polish king was an important part of the dispatches sent by the nuncio to the Roman secretariat of state. The king was concerned with creating a positive image of a ruler respecting the rights of the Roman Catholic Church. During this period several potential crises involving the state and the Church were resolved amicably.

The correspondence conducted by Archetti frequently mentions royal declarations of loyalty towards the Apostolic See and the monarch's attachment to 
Pope Pius VI. Stanisław August "silently" consented to a backstage campaign conducted by the nuncio against the election of a dissident envoy at a sejmik held in Wschowa in 1776, and disagreed with projects of additional taxes to be paid by Church institutions on royal landed estates. At the same time, the Polish monarch rather decisively insisted on assuming control over the estates of the Cistercian abbeys in Lad and Bledzew and did not meet all the demands made by Archetti regarding custody over Bishop Kajetan Sołtyk of Cracow. The king behaved in a more conciliatory fashion during the trial of Benedykt Oganowski, who having accepted ordination was subjected to Church jurisdiction although he was to be tried for earlier crimes committed as a layman. Despite the involvement of the nuncio the failed project of a legal code by Andrzej Zamoyski did not alter the way in which the king declared his total loyalty towards Pius VI and demonstrated his good will towards the papal diplomat. Archetti wrote about the monarch with sympathy and even compassion as he observed royal efforts aimed at a reform of the Commonwealth together with simultaneous political ineffectiveness sustained in particular by Russia. Stanisław August confimed his positive personal contacts with the nuncio by decorating the latter's nephew, Giovanni Battista Vertova, with the Order of St. Stanislas and the Order of the White Eagle despite the fact that the recipient's only merit was kinship with Giovanni Andrea Archetti.

Translated by Aleksandra Rodzińska-Chojnowska

\section{Bibliografia}

Beales, Derek. Joseph II. T. 2, Against the World. Cambridge: Cambridge University Press, 2013.

Borkowska-Bagieńska, Ewa. Zbiór praw sądowych Andrzeja Zamoyskiego. Poznań: Uniwersytet im. Adama Mickiewicza w Poznaniu, 1986.

Boutigny, Roland le Vayer de. De l'autorité du roy touchant l'âge nécessaire à la Profession solemnelle des Religieux. Paris: Chez Iacques Cottin, 1669.

Boutigny, Roland le Vayer de. Dell'autorità del re sopra l'età necessaria alla professione solenne de' religiosi. Opera del signor Le Vayer de Butigni' [sic!], avvocato del Parlamento di Parigi, ed ora trasportata in Lingua Italiana. Venezia: Presso Luigi Paviani, 1768 .

Butterwick, Richard. Polska rewolucja a Kościół katolicki 1788-1792. Kraków: Wydawnictwo Arcana, 2012.

Chotkowski, Władysław. Historia polityczna Kościoła w Galicji za rządów Marii Teresy. T. 1. Kraków: G. Gebethner i Sp., 1909.

Cristianopulo, Ermanno Domenico. Analisi critica del trattato del signor Levayer de Boutigny: Dell'autorità del Re sopra l'età necessaria alla professione solenne de' Religiosi (del P. Ermanno Domenico Cristianopulo, domenicano). 2 t. S.l.: s.n., 1772.

Czartoryski, Adam Jerzy. Pamiętniki i memoriały polityczne 1776-1809. Warszawa: Instytut Wydawniczy PAX, 1986.

Czeppe, Maria. „Kajetan Ignacy Sołtyk”. W Polski Słownik Biograficzny. T. 40, 386-404. Warszawa: Instytut Historii PAN, 2000-2001. 
Diariusz sejmu ordynaryjnego pod związkiem konfederacyi generalnej Obojga Narodów agitujacego się. Warszawa: Drukarnia J.K.MCI, 1776.

Dunin-Wilczyński, Zbigniew. Order św. Stanisława. Warszawa: Agencja Wydawnicza CB Andrzej Zasieczny, 2006.

Dymnicka-Wołoszyńska Hanna. „Antoni Ostrowski”. W Polski Słownik Biograficzny. T. 24, 540-546. Wrocław: Zakład Narodowy im. Ossolińskich, 1979.

Filipczak, Witold. Sejm 1778 r. Warszawa: Wydawnictwo Naukowe Semper, 2000.

Gagarin, Ivan Sergeevič, wyd. Un Nonce du Pape à la cour de Catherine II. Mémoires d'Archetti. Paris: Victor Palmé; Bruxelles: A. Vromant, 1872.

Gurowski, Rafał. „Mowa J.W. JMCI Pana Gurowskiego kasztelana przemęckiego w senacie dnia 3. października roku 1776 miana". W Zbiór mów różnych w czasie dwóch seymów ostatnich roku 1775 y 1776 mianych. T. 3, Mowy w czasie Seymu Ordynaryinego Roku 1776 od 20 dnia września do końca seymu, 165-173. Poznań: Drukarnia J.K.MCI, 1777.

Kęder, Wojciech. Stolica Apostolska wobec Rzeczpospolitej w okresie Konfederacji Barskiej. Opole: Wydawnictwo Świętego Krzyża, 2006.

Kumor, Bolesław. Dzieje polityczno-geograficzne diecezji tarnowskiej. Lublin: TN KUL, 1958.

Kumor, Bolesław. Diecezja tarnowska. Dzieje ustroju i organizacji, 1786-1985. Kraków: Polskie Towarzystwo Teologiczne, 1985.

Kumor, Bolesław. Dzieje diecezji krakowskiej do roku 1795. T. 1. Kraków: Wydawnictwo Św. Stanisława Biskupa i Męczennika, 1998.

Kurdybacha, Łukasz. Dzieje Kodeksu Andrzeja Zamoyskiego. Kraków: Czytelnik, 1951.

Leśnodorski, Bogusław. Recenzja Dziejów Kodeksu Andrzeja Zamoyskiego Łukasza Kurdybachy. Czasopismo Prawno-Historyczne 4 (1952): 466-480.

Loret, Maciej. Kościót katolicki a Katarzyna II, 1772-1784. Kraków: Druk. W.L. Anczyca i Spółki, 1910.

Loret, Maciej. „Zamach na Stanisława Augusta w świetle źródeł watykańskich”. Biblioteka Warszawska 841 (1911): 541-551.

Lutowski, Krzysztof, Marta Małkus, red. Rafał hrabia Gurowski. Szkice do XVIII-wiecznego portretu szlacheckiego. Wschowa: Stowarzyszenie Turystyczne Ziemi Wschowskiej, Stowarzyszenie Kultury Ziemi Wschowskiej, 2007.

Manikowska, Ewa. „Sztuka i dyplomacja. Kontekst rzymski kolekcjonerstwa Stanisława Augusta". W Stanisław August i jego Rzeczpospolita. Dramat państwa, odrodzenie narodu, red. Angela Sołtys, Zofia Zielińska, 267-278. Warszawa: Arx Regia. Ośrodek Wydawniczy Zamku Królewskiego, 2013.

Matuszewska, Przemysława. „Jędrzej Kitowicz”. W Polski Słownik Biograficzny. T. 12, 525-527. Wrocław: Zakład Narodowy im. Ossolińskich; Wydawnictwo Polskiej Akademii Nauk, 1966-1967.

Męclewska Marta, red. Kawalerowie i statuty Orderu Orła Białego, 1705-2008. Warszawa: Zamek Królewski w Warszawie, 2008.

Michalski, Jerzy. „Dwie misje księcia Stanisława”. W Studia historyczne z XVIII i XIX wieku. T. 1, 376-392. Warszawa: Wydawnictwo Stentor, 2007.

Michalski, Jerzy. Recenzja Dziejów Kodeksu Andrzeja Zamoyskiego Łukasza Kurdybachy. Przeglad Historyczny 42 (1951): 444-452. 
Michalski, Jerzy. „Sprawa wyboru posłów dysydentów na sejm 1776 roku”. W Kultura staropolska - kultura europejska. Prace ofiarowane Januszowi Tazbirowi w siedemdziesiątą rocznicę urodzin, red. Stanisław Bylina, 273-280. Warszawa: Wydawnictwo Naukowe Semper, 1997.

Michalski, Jerzy. Stanisław August Poniatowski. Warszawa: Instytut Historii PAN, 2009. Michalski, Jerzy. „Zmierzch prokonsulatu Stackelberga”. W Studia historyczne z XVIII i XIX wieku. T. 1, 449-499, Warszawa: Wydawnictwo Stentor, 2007.

Niemcewicz, Julian Ursyn. Pamiętniki czasów moich. Lipsk: F.A. Brockhaus, 1868.

Niemcewicz, Julian Ursyn. Pamiętniki czasów moich. T. 1. Warszawa: Państwowy Instytut Wydawniczy, 1957.

Ostrowski, Jozafat. „La Commende en Pologne et le Concordat de Wschowa en 1737”. W La Pologne au VII-e Congrès International des Sciences Historiques. Vol. 2, 175-197. Varsovie: Société Polonaise d'Histoire, 1933.

Platania, Gaetano. „Instrukcje dworu polskiego w związku z konklawe po śmierci papieża Klemensa XIV (1774)". Informationes. Biuletyn Papieskiego Instytutu Studiów Kościelnych 2 (1980): 37-54.

Raila, Eligijus. Ignotus Ignotas. Vilniaus vyskupas Ignotas Jakūbas Masalskis. Vilnius: Aidai, 2010.

Rouët de Journel, Marie-Joseph. Nonciatures de Russie d'après les documents authentiques. Vol. 1, Nonciature d'Archetti 1783-1784. Città del Vaticano: Biblioteca Apostolica Vaticana, 1952.

Rudnicki, Kazimierz. Biskup Kajetan Sołtyk 1715-1788. Kraków: Druk. W.L. Anczyca i Spółki, 1906.

Stanislas Auguste. Mémoires, wyd. Anna Grześkowiak-Krwawicz, Dominique Triaire. Paris: Institut d'Études Slaves; Société Historique et Littéraire Polonaise, 2012.

Sterna-Wachowiak, Sergiusz. „Rafał Gurowski - starosta Wschowy”. Przyjaciel Ludu 3 (1988): 10-13.

Stroynowski, Andrzej. Opozycja sejmowa w dobie rządów Rady Nieustającej. Studium z dziejów kultury politycznej. Łódź: Wyższa Szkoła Studiów Międzynarodowych w Łodzi, 2005.

Venturi, Franco. Settecento riformatore. Vol. 2, La chiesa e la repubblica dentro i loro limiti, 1758-1774. Torino: Giulio Einaudi editore, 1976.

Venturi, Salvatore. Delle Monache. Lucca: s.n., 1776.

Wisłocki, Jerzy. 1960-1961. „Gurowski Rafał h. Wczele (1716-1797)”. W Polski Słownik Biograficzny. T. 9, 170-171. Wrocław: Zakład Narodowy im. Ossolińskich; Wydawnictwo Polskiej Akademii Nauk, 1960-1961.

Włodarczyk, Tadeusz. Konkordaty. Zarys historii ze szczególnym uwzględnieniem XX wieku. T. 1. Warszawa: PWN, 1986.

Wolff, Larry. The Vatican and Poland in the Age of the Partitions. Diplomatic and Cultural Encounters at the Warsaw Nunciature. New York: Columbia University Press, 1988.

Wrana, Magdalena. Angelo Maria Durini. Poeta i polityk w purpurze. Zarys działalności literackiej, kulturalnej i politycznej nuncjusza w Polsce (1767-1772). Kraków: Collegium Columbinum, 2013.

Wyrwa, Andrzej Marek. „Ląd”. W Monasticon Cisterciense Poloniae, red. Andrzej Marek Wyrwa, Jerzy Strzelczyk, Krzysztof Kaczmarek. T. 2, Katalog męskich klasztorów 
cysterskich na ziemiach polskich i dawnej Rzeczypospolitej, 189-201. Poznań: Wydawnictwo Poznańskie, 1999.

Zając, Paweł, wyd. Ioannes Andreas Archetti (1776-1784). Vol. 1, (8 IV 1775-25 VII 1776). Acta Nuntiaturae Polonae, t. 54. Cracoviae: Academia Scientiarum et Litterarum Polona, 2013.

Zając, Paweł. „Polska i Polacy w korespondencji nuncjusza Jana Andrzeja Archettiego, 1775-1784". W Nuncjatura Apostolska w Rzeczypospolitej. Stan badań i perspektywy, red. Teresa Chynczewska-Hennel, Katarzyna Wiszowata-Walczak, 414-437. Białystok: Uniwersytet w Białymstoku, 2012.

Zając, Paweł. „ "Jeden z najszczęśliwszych dni króla Stanisława Augusta» — Grodno, 24 października 1784 r.”. W W cieniu wojen i rozbiorów. Studia z dziejów Rzeczypospolitej XVIII i początków XIX wieku, red. Urszula Kosińska, Dorota Dukwicz, Adam Danilczyk, 311-338. Warszawa: Wydawnictwo Neriton, 2014.

Zawadzki, Stanisław. „«Zwaryowany na umyśle biskup» czy ofiara intrygi? Sprawa biskupa krakowskiego Kajetana Sołtyka w 1782 r. w świetle gazetek pisanych Teodora Ostrowskiego". Praca licencjacka, Uniwersytet Warszawski, Wydział Historyczny, 2013.

Zielińska, Ewa. „Rzeczpospolita wobec zbliżenia rosyjsko-austriackiego na początku lat osiemdziesiątych XVIII w. Sprawy Barona Karla Juliusa i Biskupa Kajetana Sołtyka". Praca doktorska, Instytut Historii PAN, 2004.

Zielińska, Zofia, oprac. Correspondance de Stanislas-Auguste avec Catherine II et ses plus proches collaborateurs (1764-1796), Kraków: Wydawnictwo Arcana, 2015.

Biogram: dr hab. Paweł Zając OMI - adiunkt w Zakładzie Historii Kościoła Wydziału Teologicznego Uniwersytetu im. Adama Mickiewicza w Poznaniu. Zainteresowania badawcze: historia nuncjatury warszawskiej w XVIII w. E-mail: pawelarz@amu.edu.pl. 